Article

\title{
Virulence Potential of a Multidrug-Resistant Escherichia coli Strain Belonging to the Emerging Clonal Group ST101-B1 Isolated from Bloodstream Infection
}

\author{
Ana Carolina M. Santos ${ }^{1, *(\mathbb{D}, \text {, Rosa M. Silva }}{ }^{1}$, Tiago B. Valiatti ${ }^{1}$, Fernanda F. Santos ${ }^{1}$, \\ José F. Santos-Neto ${ }^{1}{ }^{(0}$, Rodrigo Cayô ${ }^{2,3}{ }^{(0)}$, Ana P. Streling ${ }^{3}$, Carolina S. Nodari ${ }^{3}$, Ana C. Gales ${ }^{3}$, \\ Milton Y. Nishiyama-Jr ${ }^{4} \mathbb{D}$, Eneas Carvalho ${ }^{5}$ and Tânia A. T. Gomes ${ }^{1} \mathbb{D}$ \\ 1 Disciplina de Microbiologia, Departamento de Microbiologia, Imunologia e Parasitologia-DMIP, \\ Universidade Federal de São Paulo—Escola Paulista de Medicina (UNIFESP-EPM), São \\ Paulo_SP 04023-062, Brazil; rmsilva01@unifesp.br (R.M.S.); tiagovaliatti21@gmail.com (T.B.V.); \\ ff.santos@unifesp.br (F.F.S.); josefsneto97@gmail.com (J.F.S.-N.); tatg.amaral@unifesp.br (T.A.T.G.) \\ 2 Laboratório de Imunologia e Bacteriologia—LIB, Setor de Biologia Molecular, Microbiologia e Imunologia, \\ Departamento de Ciências Biológicas-CDB, Instituto de Ciências Ambientais, Químicas e \\ Farmacêuticas-ICAQF, Universidade Federal de São Paulo_UNIFESP, Diadema—SP 09972-270, Brazil; \\ rodrigocayosilva@gmail.com \\ 3 Laboratório Alerta, Disciplina de Infectologia, Departamento de Medicina, Universidade Federal de São \\ Paulo-Escola Paulista de Medicina-(UNIFESP-EPM), São Paulo-SP 04039-032, Brazil; \\ anastreling@gmail.com (A.P.S.); carol.nodari@gmail.com (C.S.N.); ana.gales@gmail.com (A.C.G.) \\ 4 Laboratório Especial de Toxinologia Aplicada-Instituto Butantan, São Paulo-SP 05503-900, Brazil; \\ milton.nishiyama@butantan.gov.br \\ 5 Laboratório de Bacteriologia-Instituto Butantan, São Paulo—SP 05503-900, Brazil; \\ eneas.carvalho@butantan.gov.br \\ * Correspondence: carolina.mello@unifesp.br; Tel.: +55-11-5576-4848
}

Received: 20 April 2020; Accepted: 21 May 2020; Published: 30 May 2020

\begin{abstract}
Escherichia coli EC121 is a multidrug-resistant (MDR) strain isolated from a bloodstream infection of an inpatient with persistent gastroenteritis and T-zone lymphoma that died due to septic shock. Despite causing an extraintestinal infection, previous studies showed that it did not have the usual characteristics of an extraintestinal pathogenic E. coli. Instead, it belonged to phylogenetic group B1 and harbored few known virulence genes. To evaluate the pathogenic potential of strain EC121, an extensive genome sequencing and in vitro characterization of various pathogenicity-associated properties were performed. The genomic analysis showed that strain EC121 harbors more than 50 complete virulence genetic clusters. It also displays the capacity to adhere to a variety of epithelial cell lineages and invade T24 bladder cells, as well as the ability to form biofilms on abiotic surfaces, and survive the bactericidal serum complement activity. Additionally, EC121 was shown to be virulent in the Galleria mellonella model. Furthermore, EC121 is an MDR strain harboring 14 antimicrobial resistance genes, including $b a_{\mathrm{CTX}-\mathrm{M}-2}$. Completing the scenario, it belongs to serotype O154:H25 and to sequence type 101-B1, which has been epidemiologically linked to extraintestinal infections as well as to antimicrobial resistance spread. This study with E. coli strain EC121 shows that clinical isolates considered opportunistic might be true pathogens that go underestimated.
\end{abstract}

Keywords: Escherichia coli; extraintestinal; intestinal; multidrug resistance; hybrid pathogen; bloodstream infection; DEC; MDR; virulence; ST101 


\section{Introduction}

Escherichia coli is one of the most frequent pathogens isolated from bloodstream infections (BSI) around the world [1-5]. Despite all knowledge of extraintestinal infections due to pathogenic E. coli, the number of severe infections and outbreaks caused by these pathogens is rising $[2,6]$. Moreover, many of these infections are caused by multidrug-resistant (MDR) strains, leading to a higher burden of disease [7-10].

The term extraintestinal pathogenic E. coli (ExPEC) is used to define strains recovered from any extraintestinal infection in humans or animals. Although many virulence factors are associated with the pathogenicity of this group, it is difficult to identify or classify ExPEC strains based on a specific group of virulence genes [11,12]. Some studies developed molecular virulence patterns that define strains that harbor intrinsic extraintestinal virulence potential [13] or are capable of causing urinary tract infection [14]. These molecular patterns are useful tools to track ExPEC both in the gastrointestinal tract or environment (soil, water, food), enabling the search for some ExPEC reservoirs [13-15].

Even though such methods may recognize the most virulent strains, they fail in identifying a considerable part of isolates recovered from clinical samples $[14,16]$. The reason is that infections take place as a result of an imbalance between the pathogen virulence potential and the host immune defenses, which makes it sometimes unclear whether the infection is being caused by a true pathogen or by an opportunistic strain, considering that it is accepted that nonpathogenic commensals can cause disease in immunocompromised patients [12,17].

The ExPEC prototype strains CFT073, 536, J96, and RS218 belong to phylogroup B2, and all showed the phenotypic capacity to adhere to and invade a variety of epithelial cells, survival the complement bactericidal activity, and produce biofilms [18-25]. Nevertheless, these features were expressed at different levels in clinical isolates [22,26,27]. Moreover, most of the information related to virulence properties expression assessed in vitro were derived from strains from phylogroups B2 and D $[12,24]$. Although strains from phylogroup B1 were isolated worldwide from extraintestinal sites, they are neglected, and few were the studies that analyzed their virulence potential. In general, these strains were considered opportunist pathogens causing infection in immunocompromised patients, but few studies evaluated the patients' conditions on the course of infection [11,28]. Landraud et al. [29] have shown that sepsis severity is not exclusively related to the phylogroup origins or the classification of intrinsic virulence.

Considering this, the use of epidemiologic data and multilocus sequence typing (MLST) for the identification of strains belonging to major pathogenic clonal groups could help in the determination of the potential pathogenic role played by an E. coli strain [30-32].

The emergence of MDR E. coli strains calls attention to the spread of clones carrying virulence along with resistance-encoding genes, making the control of these pathogens potentially difficult [2,33-37]. In this context, ST131 is an MDR high-risk clonal group widely disseminated and studied worldwide. Other clonal groups, presenting MDR phenotype, like ST405, ST38, and ST648, have also emerged and are already considered of global risk [38]. On the other hand, some STs presenting MDR phenotype, although being isolated around the world, have not yet had their pathogenic potential determined [39-42].

The spread of MDR pathogens is a major public health concern that needs to be adequately addressed towards efficient control. Based on that, the World Health Organization (WHO) called attention to this problem and the need for alternative therapeutic options for the treatment of MDR infections [43]. The development of vaccines and antivirulence compounds could be alternative approaches to combat MDR strains, especially those showing pan drug resistance (PDR) phenotype [44,45]. However, for these alternatives to be effective, advanced knowledge is necessary, since not all pathogenic strains share the same virulence factors, and the use of the most prevalent virulence factors as targets can be problematic as they can adversely affect the gut microbiota.

It is well accepted that the phylogenetic grouping of $E$. coli keeps a very good correlation with the virulence potential of bacterial isolates $[12,46,47]$. Recently, epidemiological data have shown 
that nonvirulent strains are mostly classified in the phylogenetic group A, while diarrheagenic E. coli (DEC) are B1, and ExPEC are mainly B2 [12,17,48]. However, the fact that most E. coli virulence factors are carried on mobile genetic elements (e.g., plasmids and pathogenicity islands) may eventually cross these phylogenetic boundaries and promote the appearance of potential pathogens in atypical phylogroups $[17,49]$.

Thus, a global analysis of virulence and resistance characteristics of $E$. coli causing extraintestinal infections, especially those escaping typical ExPEC classification, is essential for the understanding of the infections they cause.

This study used various methodological approaches to characterize the pathogenic potential of an extraintestinal E. coli isolate that would otherwise be considered an opportunistic, despite leading to the patient's death. In fact, the withdrawn conclusion is that the pathogenic characteristics of E. coli strains causing extraintestinal infections are not fully contemplated by the molecular analysis currently applied. Finally, the more that is known about virulence mechanisms and drug resistance of these pathogens, the more proper the addressing of measures to implement alternative therapies and control MDR spread will be.

\section{Materials and Methods}

\subsection{Bacterial Strain}

E. coli strain EC121 was isolated from the blood of a patient diagnosed with T-zone lymphoma and persistent infectious gastroenteritis, who had been hospitalized in a tertiary hospital located in the city of São Paulo, Brazil, in 2007. The patient died due to septic shock two days after the isolation of the agent. Strain EC121 was kept frozen in glycerol at $-80{ }^{\circ} \mathrm{C}$ in the ENTEROBACTERIALES-EXTRAINTESTINAL-EPM-DMIP collection $n^{\circ}$ A27A7C3. The initial virulence and resistance characterization showed that EC121 strain belonged to phylogroup B1, presented an MDR phenotype by routine susceptibility testing, and harbored seven known virulence genes (fim, hra, cvaC, ompA, ompT, sitA, and iroN) among 30 virulence factors related to ExPEC that were screened (afaBC III, afaE-8, bmaE, tsh, $\operatorname{lp}$, fimA, hra, iha, mat, papA, papC, sfaDE, ibe10, ompA, chuA, ireA, iroN, irp2, iucD, sit A, cvaC, kpsMT II, kpsMT III, ompT, traT, cnf1, hlyA, hlyF, sat, and vat). According to the presence of these genes, it was considered an opportunist strain because it harbored none of the virulence factors commonly involved in the characterization of ExPEC (presence of two of the following genes: papA/C, sfaDE, afaBC, iuc/iut, and kpsMTII) [28]. Strain EC121 was obtained from clinical routine after laboratory procedures. No additional procedure was performed to acquire any bacterial strain, so the consent form was not required as determined by the Brazilian National Health Council $n^{\circ} 466 / 12$ and 510/16. All patient information was obtained from medical records, and the research was done with the approval of the local Research Ethics Committee of the Federal University of São Paulo-UNIFESP/São Paulo Hospital (CEP 2031/08 from December 2008 and CEP N 7140160317 from April 2017).

\subsection{Total DNA Extraction, Whole-Genome Sequencing (WGS), and Genome Assembly}

The total bacterial DNA was extracted using Wizard ${ }^{\circledR}$ Genomic DNA Purification Kit (Promega, Madison, WI, USA) following the manufacturer's protocol. The extracted DNA was sequenced in an Illumina ${ }^{\circledR}$ Hiseq1500 (Illumina, San Diego, CA, USA), using the Rapid protocol to obtain $2 \times 250$ paired-end reads, according to the manufacturer's recommendations. Raw data were processed with Trimmomatic, and then the paired-end reads were assembled using SPAdes (version 3.12.0), with default parameters, and careful mode on [50].

\subsection{Genomic Analyses and Annotation}

The obtained draft genome was classified by PlasFlow algorithm [51] and submitted to various online bioinformatics platforms of the Center of Genomic Epidemiology (CGE) pipeline to determine 
(i) sequence types [52] for both E. coli MLST schemes (MLST-2.0); (ii) serotype (SerotypeFinder-2.0) [53]; (iii) presence and types of plasmid replicons (PlasmidFinder-2.0) [54]; (iv) presence of resistance genes (ResFinder-3.1) [55]; and (v) STEC virulence factors (VirulenceFinder-2.0) [56]. PHASTER [57] and PHAST [58] were used to detect bacteriophage sequences in each contig of the draft genome.

The genome was annotated using Pathosystems Resource Integration Center (PATRIC) Comprehensive Genome Analysis service that uses RASTtk [59]. Each sequence that was assigned as a virulence factor in PATRIC's database was manually submitted to BLAST/NCBI [60] and UniProt [61] to validate the virulence factors, to obtain all information about the virulence genes detected, to evaluate the completeness of the sequence, and to determine its homology concerning the RefSeq protein in Swiss-Prot. PATRIC [59] service was also used to build a phylogenetic tree using RA $\times$ ML-VI-HPC or Fast tree 2, where all representative $E$. coli genomes from different pathotypes were used to construct the tree, as well as the deposited genomes of E. coli strains belonging to ST101 complex from diverse sources. The tree was built based on the concatenated sequence of all shared proteins among all genomes using $\mathrm{RA} \times \mathrm{ML}$ or FastTree2. To construct the phylogenetic tree of EC121 and representative E. coli pathotypes, two Escherichia fergusonni strains ATCC 35469 and NCTC12128 were used as outgroups. To build the phylogenetic trees, a total of 114 public genomes were randomly selected among the published genomes from the ST101 complex (ST101, ST359, ST2480, ST5957, and ST6388) using the PATRIC's Genomes search tool. The E. fergusonni strains ATCC35469, E. coli str IAI1, E. coli O157:H7 str Sakai, E. coli O104:H4 str 2011c-3493 were used as outgroup. The phylogenetic tree's final layout and annotation were completed using iTOL v.4 [62]. The annotated genome was submitted to MacSyFinder from Galaxy@Pasteur [63] to detect CAS-CRISPR sequence type and the presence of secretion systems [64,65].

\subsection{Data Availability}

The EC121 Whole Genome Shotgun project has been deposited at DDBJ/ENA/GenBank under the accession VYQD00000000. The version described in this manuscript is version VYQD01000000.

\subsection{Serum Agglutination Assay for Typing the $O$ and $H$ Antigens}

Serum agglutination assay was carried out following the standard methodology as described by Orskov and Orskov [66] for serotyping, using O serum against $\mathrm{O} 100$ and O154, and $\mathrm{H}$ serum against H25 provided by the Centers for Disease Control and Prevention (CDC, Atlanta, GA, USA).

\subsection{Antimicrobial Susceptibility Testing}

The minimum inhibitory concentration (MIC) was determined using the broth microdilution method, following the European Committee on Antimicrobial Susceptibility Testing (EUCAST) recommendations and breakpoints [67]. The following antimicrobials (Sigma, Saint Louis, MO, USA) were tested: ampicillin, piperacillin/tazobactam, ceftriaxone, ceftazidime, cefepime, aztreonam, ertapenem, imipenem, meropenem, ciprofloxacin, amikacin, gentamicin, tigecycline, colistin, polymyxin B, trimethoprim/sulfamethoxazole, and chloramphenicol. E. coli ATCC 25922 and Pseudomonas aeruginosa ATCC 27853 were used as quality control strains.

\subsection{Plasmid DNA Extraction and Analysis}

Bacteria were cultivated in tryptic soy broth (TSB-Difco, Sparks, MD, USA) at $37^{\circ} \mathrm{C}$, in a static incubator for approximately $18 \mathrm{~h}$, and $1 \mathrm{~mL}$ of the culture was submitted to plasmid alkaline extraction protocol [68]. E. coli strain 39R861 was used as a plasmid mass reference ladder and as control of extraction [69]. The plasmid extract was submitted to electrophoresis in an agarose gel $(0.8 \%)$ in tris-borate-EDTA (TBE) buffer, stained with ethidium bromide solution $(5 \mu \mathrm{g} / \mathrm{mL})$, analyzed using Molecular Imager ${ }^{\circledR}$ Gel Doc $^{\mathrm{TM}} \mathrm{XR}^{+}$with Image Lab ${ }^{\mathrm{TM}}$ Software System from Bio-Rad (Hercules, CA, USA). The molecular weight of each plasmid was calculated as previously described [70], based on its migration distance in agarose gel of five different extraction assays followed by electrophoresis. 


\subsection{In Silico Plasmid Analysis}

The following strategies were used to accomplish plasmid analysis. First, the draft genome was analyzed by PlasFlow [51] to classify the possible source of each contig (as chromosomal or plasmid); subsequently, it was submitted to CGE to identify the contigs that contained replicons. The contigs containing replicons were analyzed using the Standard Nucleotide BLAST in the National Center for Biotechnology Information (NCBI).

\subsection{Conjugation Assay}

Conjugation assay was conducted to resolve the EC121 conjugative plasmids. In the mating pair, strain EC121 was the donor strain, whereas E. coli K-12 derived strains, J53 [71] and C600 [72], resistant to sodium azide, were the recipient strains. Conjugation was performed using overnight cultures of the donor and the recipient strains grown in LB, in the proportion of 1:2, respectively. One milliliter of fresh LB was added to the mating mixtures, following $3 \mathrm{~h}$ incubation at $37^{\circ} \mathrm{C}$ under static condition. After the incubation period, $100 \mu \mathrm{L}$ of each mating mixture was plated into selective MacConkey agar plates (Difco, Sparks, MD, USA) supplemented with three different antibiotic combinations $(20 \mu \mathrm{g} / \mathrm{mL}$ gentamycin and $100 \mu \mathrm{g} / \mathrm{mL}$ sodium azide; $2 \mu \mathrm{g} / \mathrm{mL}$ cefotaxime and $100 \mu \mathrm{g} / \mathrm{mL}$ sodium azide; and $30 \mu \mathrm{g} / \mathrm{mL}$ chloramphenicol and $100 \mu \mathrm{g} / \mathrm{mL}$ sodium azide). The colonies that grew in the selective medium (transconjugants) were purified in the same selective medium and then stored for further characterization.

\subsection{Characterization of Conjugative Plasmids}

The transconjugants obtained were analyzed by PCR for the presence of virulence encoding-genes, $b l a_{\mathrm{CTX}-\mathrm{M}-2}$ resistance gene, and determination of the replicon types. Additionally, the susceptibility profile of the transconjugants was determined by the minimum inhibitory concentration (MIC) method $[16,73,74]$.

\subsection{Determination of the Lowest Bacterial Inoculum Which Was Resistant to Human Serum Complement}

The lowest bacterial inoculum resistant to serum was determined to access the bacterial serum-resistance. Lyophilized human complement serum (Sigma, Saint Louis, MO, USA) was reconstituted in sterile phosphate-buffered saline (PBS). The assay was performed in 96-wells plates, where complement serum was distributed in each well ( $90 \mu \mathrm{L}$ per well). Bacteria were grown overnight at $37^{\circ} \mathrm{C}$, serially diluted $(1: 10)$ in complement serum until $10^{-10}$, and incubated at $37^{\circ} \mathrm{C}$. Aliquots of $10 \mu \mathrm{L}$ of each well were seeded onto MacConkey agar plates after $30 \mathrm{~min}, 1 \mathrm{~h}$, and $2 \mathrm{~h}$ of incubation. Simultaneously, another assay was performed with previously heat-inactivated serum as control. The E. coli strains J96 and C600 were used as resistant and susceptible controls, respectively [75]. The lowest bacterial inoculum resistant to human complement was determined by the last bacterial dilution, which had bacterial growth onto MacConkey after the challenge. For each assay, the initial bacterial inoculum was determined by diluting bacteria in PBS, plating in MacConkey agar, and CFU counting. The data was reported in CFU/mL. Biological assays were performed in triplicates.

\subsection{Biofilm Formation on Abiotic Surfaces}

Biofilm formation was evaluated on polystyrene and glass surfaces as described by Lima et al. [73] in a 24 h-assay using the following media: Dulbecco's Modified Eagle's Medium (DMEM) high-glucose and TSB. Each assay was performed in biological and experimental triplicates. The EAEC 042 and laboratory E. coli HB101 strains were used as positive and negative controls, respectively; in all assays, a noninoculated well was used as control of dye retention, and the prototype strain CFT073 as an ExPEC control. 


\subsection{Cell Culture and Maintenance}

HeLa (ATCC ${ }^{\circledR}$ CCL- ${ }^{\mathrm{TM}}$ ), intestinal Caco-2 $\left(\right.$ ATCC $^{\circledR}{ }^{\circledR T B}-37^{\mathrm{TM}}$ ), and bladder T24 (ATCC ${ }^{\circledR}$ HTB- $4^{\mathrm{TM}}$ ) cell lineages were used to evaluate the ability of strain EC121 to interact with eukaryotic epithelial cells. HeLa and Caco-2 cells were cultured in DMEM, high glucose, GlutaMax ${ }^{\mathrm{TM}}$ (Gibco- ThermoFisher Scientific, Grand Island, NY, USA), supplemented with 10\% bovine fetal serum (BFS) (Gibco, Brazil), 1\% nonessential amino acids (Gibco, Grand Island, NY, USA), and $1 \times$ penicillin-streptomycin-neomycin (PSN) antibiotic mixture (Gibco, Grand Island, NY, USA). T24 cells (ATCC HTB-4) were cultured in McCoy 5A (modified) media (Sigma, Saint Louis, MO, USA), supplemented with $10 \%$ of BFS and $1 \times$ PSN antibiotic mixture. All lineages were kept at $37^{\circ} \mathrm{C}$ in an atmosphere of $5 \% \mathrm{CO}_{2}$. For all assays, cell suspensions containing $1 \times 10^{5}$ cells $/ \mathrm{mL}$ were seeded in 24-well plates, with or without glass coverslips for qualitative or quantitative assays and cultured from two up to 10 days until reaching confluence.

\subsection{Adherence Assays in HeLa, Caco-2, and T24 Cells}

The adherence properties of EC121 were evaluated qualitatively and quantitatively. In both assays, the epithelial cells were washed three times with PBS, and $1 \mathrm{~mL}$ of DMEM, high glucose, GlutaMax supplemented with $2 \%$ of BFS, was added to HeLa and Caco-2, and $1 \mathrm{~mL}$ of McCoy $5 \mathrm{~A}$ modified media, supplemented with $2 \%$ of BFS was added to T24 cells. After bacterial inoculation, the qualitative and quantitative assays were incubated for $3 \mathrm{~h}$ at $37^{\circ} \mathrm{C}$, then washed three times with PBS and processed according to the type of the assay. The qualitative assays were performed with all cell lineages (HeLa, T24, and Caco-2) using $20 \mu \mathrm{L}$ of an inoculum obtained from standardized bacterial cultures grown overnight; after the incubation period and washes, preparations were fixed and stained as described previously [76]. The quantitative assay was carried out using HeLa cells in full confluency to evaluate the efficiency of the EC121 adherence in the presence and absence of $2 \%$ D-mannose. The multiplicity of infection (MOI) of 50, obtained from an overnight culture, washed and adjusted in PBS, confirmed by O.D. and bacterial count, was used as inoculum. After incubation and washes, the cells were lysed by adding $1 \mathrm{~mL}$ of sterile bi-distilled water, which was recovered, diluted, and plated onto MacConkey agar for quantification as previously described [77]. The assays were performed in biological duplicates and experimental triplicates, and the data were expressed as the mean and standard error of the mean (SEM). The E. coli strains C1845, CFT073, and C600 were used for comparison.

\subsection{Short Period Interaction and Invasion Assay in Caco-2 and T24 Cells}

The invasion assays were carried out using Caco-2 and T24 cells in full confluency, as described by Martinez et al. [78], with modifications, in two sets of plates simultaneously. The infection was done using a MOI of 50 , and the assays were incubated for $2 \mathrm{~h}$, at $37^{\circ} \mathrm{C}$, in a normal atmosphere. After this period, one plate set was washed three times with PBS and incubated again with PBS containing $100 \mathrm{\mu g} / \mathrm{mL}$ of amikacin for $1 \mathrm{~h}$ at $37^{\circ} \mathrm{C}$ to kill all extracellular bacteria. After the incubation period, the assay was washed three times to remove all antibiotics, cells were lysed with water, and the well contents were collected, diluted, and plated onto MacConkey agar to obtain the number of internalized bacteria. The other set was washed with PBS three times, the cells were lysed, and contents of each well were collected, diluted, and plated to obtain the total number of bacteria interacting with the cells in the period. An aliquot of the PBS recovered from the last wash after incubation with amikacin was collected and plated without dilution, to ensure that the treatment had killed all extracellular bacteria. The total interaction value was the percentage of the total bacteria associated with the cells in relation to the initial inoculum. The invasion index was determined by the ratio between the number of internalized bacteria and the initial inoculum, expressed in percentage. Escherichia albertii strain 1551-2 eae::Km was used as adherent and noninvasive control [79], E. coli strain C600 as a negative control, and the CFT073 as an ExPEC control. The assays were performed in biological and experimental triplicates, and data were reported as SEM. 


\subsection{In Vivo Assay in Galleria Mellonella Virulence Model}

The full virulence potential of EC121 was evaluated using the virulence model of G. mellonella, as previously described [80,81]. Briefly, $10 \mathrm{~mL}$ of logarithmic phase cultures were washed twice and adjusted to the optical density of 0.7 (O.D.595) in $0.85 \% \mathrm{NaCl}$ and serially diluted to obtain a bacterial concentration of $1 \times 10^{6} \mathrm{CFU} / \mathrm{mL}$. Volumes of $10 \mu \mathrm{L}$ of the bacterial suspension were injected in the left larvae proleg using a Hamilton syringe (26S gauge, $50 \mu \mathrm{L}$ capacity). The tests were performed in three independent assays, each of them using five larvae per bacterial strain tested. The E. coli strains CFT073 and C600 were used as positive and negative controls, respectively, and saline injection as the procedure control.

\subsection{Statistical Analyses}

Student t-test was applied to calculate statistical significance. For biofilm production, the Wilcoxon matched-pairs test correction was used, and for the cell interaction and invasion assays, the Wilcoxon-Mann-Whitney test was applied. The Kaplan-Meier survival curve was used for survival analysis, and the difference between the groups was determined by log-rank (Mantel-Cox) test and Gehan-Breslow-Wilcoxon test. The threshold for statistical significance was a $p$-value $<0.05$. The analyses were performed in Prism 5.0 (GraphPad Prism Software, Inc.).

\subsection{Ethics Statements}

The human cell lineages used in this study were all commercially acquired, T24 (ATCC ${ }^{\circledR}$ HTB- $4^{\mathrm{TM}}$ ) from Banco de Células do Rio de Janeiro (BCRJ) (Rio de Janeiro, RJ, Brazil), and HeLa (ATCC ${ }^{\circledR}$ CCL-2 ${ }^{\mathrm{TM}}$ ) and Caco-2 (ATCC ${ }^{\circledR}$ HTB-37 ${ }^{\mathrm{TM}}$ ) cell lineages from Instituto Adolfo Lutz (IAI) (São Paulo, SP, Brazil).

\section{Results}

\subsection{Genetic Characterization and In Silico Analysis}

The genome assembly of the strain EC121 generated 143 contigs, with a total genome, predicted a size of 5,119,556 bp, and 50.43\% of GC content. PlasFlow algorithm identified 43 of 143 contigs as chromosomal and the other 66 contigs on plasmids. The contigs assigned to plasmids comprised at least 426,419 bp of the genome.

\subsubsection{EC121 Belongs to Serotype O154:H25, ST101-B1, and is Related to Diarrheagenic E. coli}

MLST analyses showed that the EC121 strain belonged to the ST101/ST88, according to the Warwick and Pasteur MLST schemes, respectively. Serotype determination by sequencing analysis was inconclusive, because two possible serotypes, O154:H25 and O100:H25, could be assigned. Using specific serum agglutination assays, it was determined that strain EC121 expressed the O154 antigen. Thus, it was characterized as belonging to serotype O154:H25. Moreover, group IV capsule- encoding genes were identified on its genome.

A phylogenetic tree built using reference E. coli strains from all pathotypes showed that EC121 was related to diarrheagenic E. coli (DEC) strains, since it was positioned in a clade closely associated with Shiga toxin-producing E. coli (STEC) (Figure 1).

A second phylogenetic tree was built with 95 strains available at the NCBI, which belonged to the ST101 complex and were recovered from distinct sources (Figure 2, Table S1). Analysis of the tree showed that the majority of the strains of this ST are MDR, many of them carrying $m c r-1$ (mobile colistin resistance gene), a variety of $\beta$-lactamases (bla ${ }_{\mathrm{CTX}-\mathrm{M}}$-like, bla $\mathrm{OXA}_{\mathrm{A}}$-like, and bla $_{\mathrm{NDM}}$-like) and genes related to fosfomycin resistance (fos $A 3$ ). Interestingly, these strains were isolated from food, environment, animals, and humans, as part of the microbiota or involved in both intestinal and extraintestinal infections, in all continents. Among the strains isolated from human infections (Figure S1 and Table S1), most were diagnosed as extraintestinal pathogens (28 strains), while three were intestinal 
pathogens; among the latter, one was STEC, and one was enterotoxigenic E. coli (ETEC). Regarding the isolates from food and animals, seven strains were identified as STEC (Figure 2, Figure S1, and Table S1), showing that ST101 is associated with intestinal and extraintestinal infection, and it is a clonal group associated with MDR phenotype. The full mobile resistome and isolation data (accession number, year and country of isolation, etc.), related to strains from the ST101 complex used to build the phylogenetic trees, are provided in Table S1.

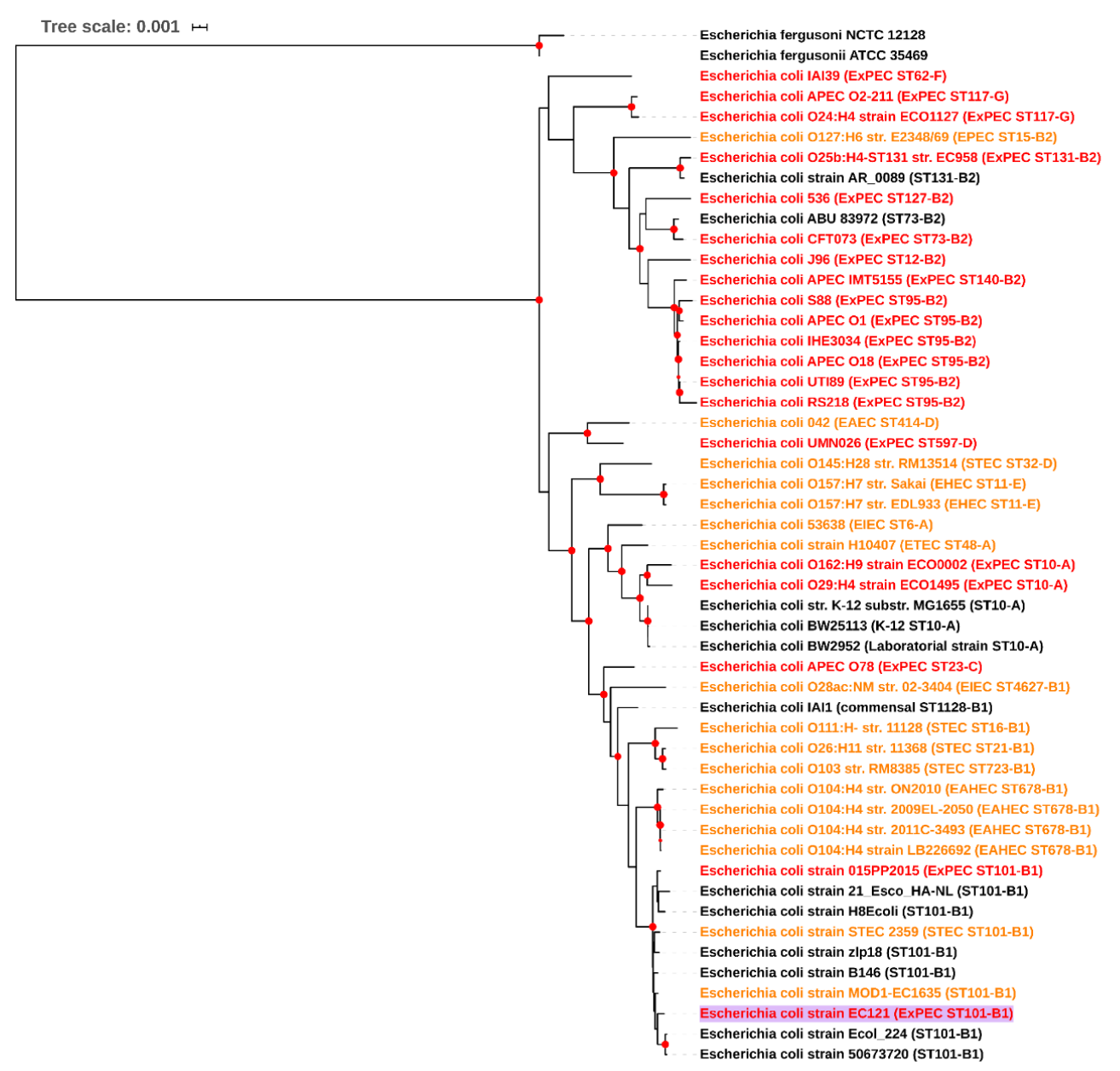

Figure 1. EC121 phylogenetic tree. A phylogenetic tree was built with genomes of reference Escherichia coli strains, of relevant pathogenic strains from all E. coli pathotypes, and some strains from ST101, using maximum likelihood-based algorithm $(\mathrm{RA} \times \mathrm{ML})$ in PATRIC. In parenthesis, the strain pathotype (when known), the sequence type, and phylogroup, according to ClermonTyping [82], are depicted. The strains' names are colored according to the following information: diarrheagenic E. coli strains are in orange; extraintestinal pathogenic E. coli strains in red; commensal, or strains with nonreported origin in black. In bold and with a lilac label background is the strain studied in present work. Bootstraps higher than 90 are denoted in the tree as red dots in the nodes.

\subsubsection{EC121 Harbors Genes Involved in Virulence and Stress Response}

The EC121 genome annotation showed that strain EC121 contained 5175 coding sequences (CDS), 82 tRNA, and 13 rRNA. One CRISPR locus was identified as type 1-IE and presented two arrays and 30 CRISPR-repeat regions (Figure 3A). Among the CDSs annotated, 702 corresponded to putative proteins designated as hypothetical proteins, and 4473 CDS to putative proteins with functional assignments. Of interest, 221 genes were reported as belonging to systems involved in response to stress, virulence, and defense (Table 1 and Figure 3B,C). 


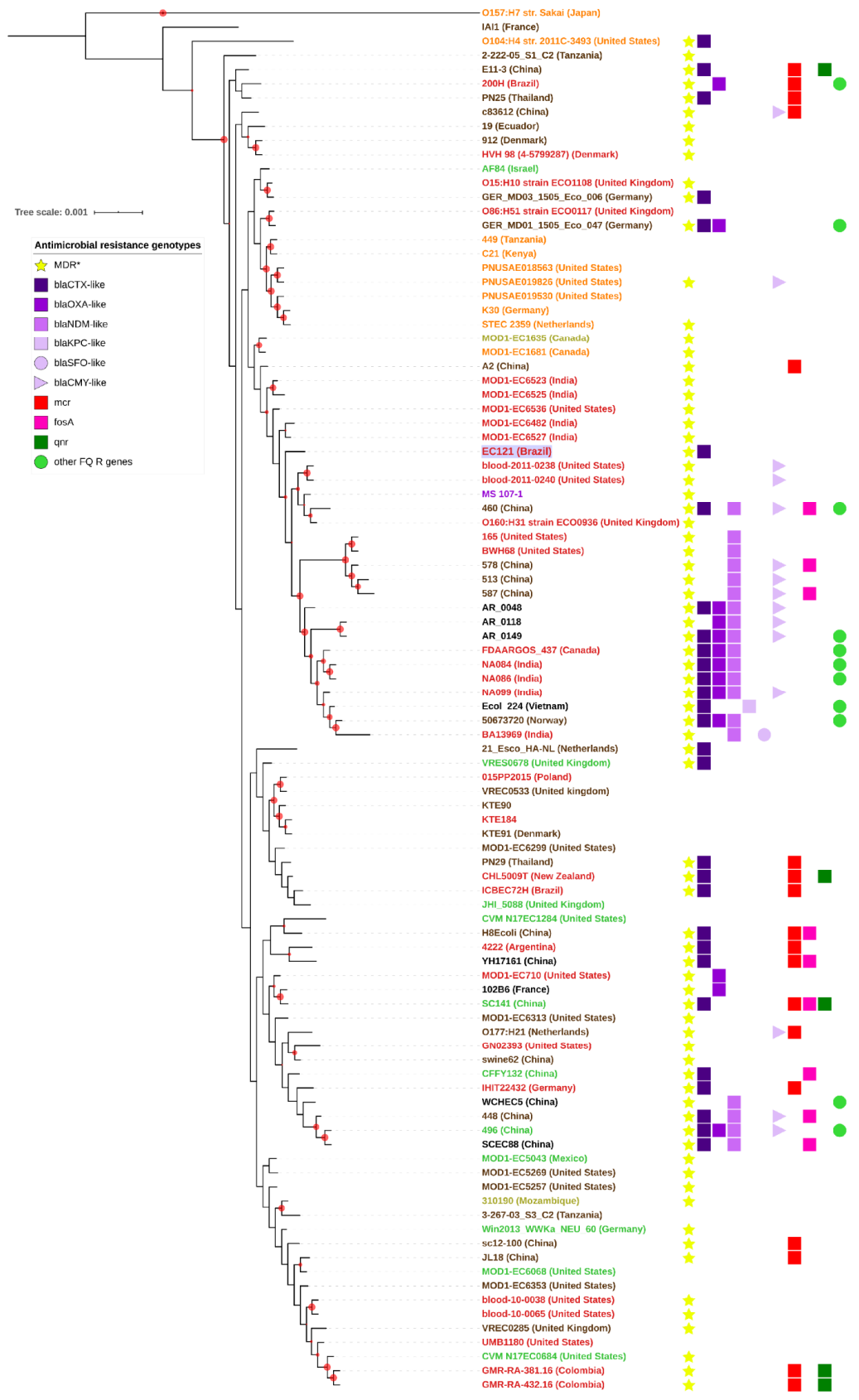

Figure 2. ST101 complex phylogenetic tree. The phylogenetic tree was built using 95 E. coli strains from the ST101 complex (ST101, ST359, ST2480, ST5957, and ST6388) from diverse sources and countries, using all shared proteins on FastTree2 to build the tree. E. coli strains IAI1, E. coli O157:H7 str Sakai, and E. coli O104:H4 str 2011c-3493 are used as outgroups. Bootstraps higher than 50 are denoted in the tree as red dots in the nodes. The strains' names are colored according to sources or host diseases; Shiga toxin-producing E. coli (STEC) are in orange independently of the origin; diarrheagenic E. coli (DEC) strains in yellow; extraintestinal pathogenic E. coli (ExPEC) strains in red; isolates from microbiota in brown; isolates from retail food or the environment in green; strains with nonreported sources in black. A strain isolated from Crohn's disease is in purple. EC121 is in bold and with a lilac label background. When known, the country where the strain was isolated is in parentheses. * All strains that are resistant to three or more antimicrobial classes were designed as multidrug resistant (MDR). The other FQ (fluoroquinolone) resistance genes detected were the mobile genes qepA and aac (6')-Ib-cr. Mutations that confer resistance to FQ were not considered to build the antimicrobial resistance (AMR) genotype information in this tree. 
A

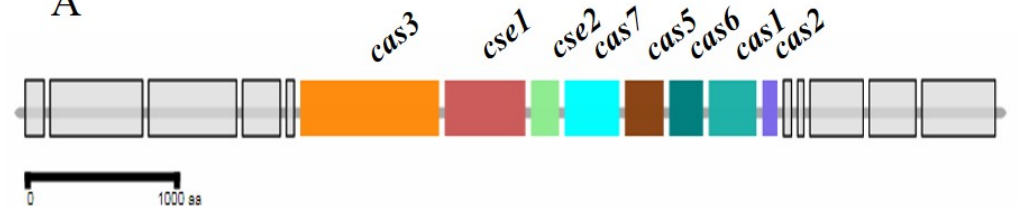

B

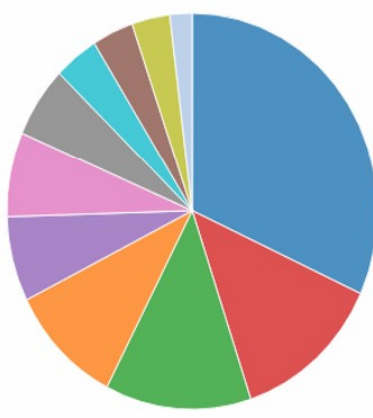

Subsystem (Subsystems, Genes)

METABOLISM $(115,933)$

- STRESS RESPONSE, DEFENSE, VIRULENCE $(47,221)$ - PROTEIN PROCESSING $(46,274)$

ENERGY $(36,342)$

CELLULAR PROCESSES $(25,204)$

MEMBRANE TRANSPORT $(25,124)$

DNA PROCESSING $(21,121)$

RNA PROCESSING $(14,75)$

- CELL ENVELOPE $(13,129)$

MISCELLANEOUS $(12,83)$

REGULATION AND CELL SIGNALING $(7,46)$
C

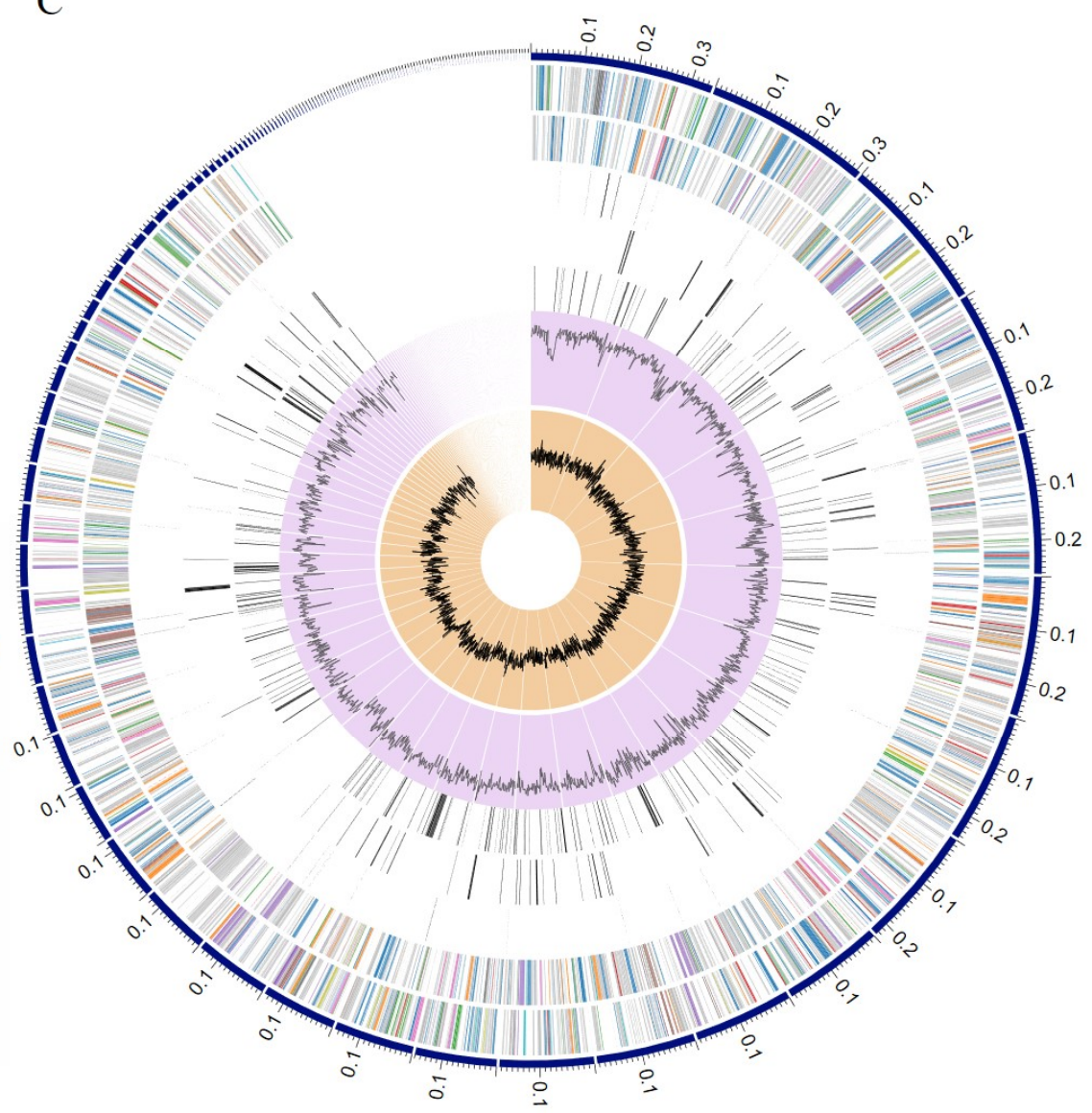

Figure 3. CRISPR locus composition and biological systems assignment in EC121. (A)-Genomic architecture representation of CRISPR locus in the EC121 genome; the image was obtained in MacSyFinder from genome annotation; (B)-Representation of EC121 genome composition in subsystems based on protein biological data obtained in silico; (C) -EC121 schematic genome composition, based on annotation, ordered by contig size. In the circle from outer to the inner portions: forward strand, reverse strand, RNA related genes, antimicrobial resistance, virulence factors, GC content, and GC skew. The colors in forward and reverse strands correspond to the subsystems presented in B. Figure 3B,C were obtained using the comprehensive genome analysis service at PATRIC. 
Table 1. EC121 annotation overview. ${ }^{a}$

\begin{tabular}{ll}
\hline Protein Features & Occurrence \\
\hline Hypothetical proteins & 702 \\
Proteins with functional assignments & 4473 \\
Proteins with E.C. $^{b}$ number assignments & 1300 \\
Proteins with G.O. $^{b}$ assignments & 1076 \\
Proteins with pathway assignments $_{\text {Proteins with PLfam }}^{b}$ assignments & 911 \\
Proteins with PGfam $^{b}$ assignments & 5063 \\
\hline
\end{tabular}

${ }^{a}$ Results obtained using PATRIC annotation service; ${ }^{b}$ Abbreviations: E.C. number-enzyme commission universal; G.O.-Gene Ontology Consortium; PLfam- PATRIC genus-specific family; PGfam- PATRIC cross-genus family.

Analysis using the MacSyFinder tool identified ten types of V secretion system proteins, nine of which were from type T5aSS and one from T5cSS (EhaG) (Table S2). One type III secretion system similar to Salmonella T3SS, and an incomplete type VI secretion system that carried only tssB, tssD, tssE, tssH, and tssI genes were also present (Table S2).

All genes that were reported by the PATRIC virulence factor database were manually curated to provide information about their full sequence. As shown in Table 2, Tables S3 and S4, the genome of the EC121 strain encodes multiple adhesins, invasins, iron uptake systems, and genes involved with the evasion of the host immune system. By the position of strain EC121 in the pathotype phylogenetic tree, some of these virulence factors are related to the pathogenesis of DEC, specifically of STEC and ETEC (Table 2 and Table S3). Other virulence factors found were related to Salmonella spp. (PagN adhesin and systems associated with immune evasion and macrophage survival) and Shigella spp. (genes associated with intracellular survival and spread). Moreover, many accessory genetic clusters associated with the bacterial ability to cause extraintestinal infections, i.e., genes involved with biofilm formation, adherence to extraintestinal cells, iron acquisition, and immune evasion, were also detected in the EC121 genome. Furthermore, other clusters associated with urinary tract infections (UTI) were detected (Table 2 and Table S3).

Table 2. Complete virulence factors identified.

\begin{tabular}{|c|c|c|c|c|}
\hline \multirow[t]{2}{*}{ Virulence Traits } & \multicolumn{4}{|c|}{ Associated with Virulence In } \\
\hline & Other Genera & DEC & ExPEC & Various \\
\hline $\begin{array}{l}\text { Colonization and } \\
\text { invasion }\end{array}$ & $\begin{array}{l}\text { MlaA, MsbB, Sfm, } \\
\text { MisL, IcsP }\end{array}$ & $\begin{array}{l}\text { Lpf-1 } 1_{\mathrm{O} 26}, \text { EhaG, } \\
\text { Hcp, Elf, EhaA, } \\
\text { EhaB, CFA-I }\end{array}$ & $\begin{array}{l}\text { FdeC, Pix, Ygi, Yad, Yeh, } \\
\text { Yra, Yfc, YchO, IbeB, IbeC, } \\
\text { EptC, OmpA }\end{array}$ & $\begin{array}{l}\text { Type } 1 \text { Fimbriae } \\
\text { (H191), Ecp, Curli }\end{array}$ \\
\hline Immune system evasion & $\begin{array}{l}\text { SodB, TrxA, SirA, } \\
\text { FpkA }\end{array}$ & & $\begin{array}{l}\text { Iss, OmpTpa }{ }^{\mathrm{a}}, \mathrm{OmpTc}^{\mathrm{a}}, \\
\text { Mig-14, HlyF }\end{array}$ & RelA \\
\hline Iron acquisition system & & & & $\begin{array}{l}\text { Sit, Iro, Fhu, } \\
\text { Enterobactin }\end{array}$ \\
\hline Regulators & $\begin{array}{l}\text { DsbA, DegP, SlyA, } \\
\text { CpxAR }\end{array}$ & EvgAS & DsbAB, PhoPQ & QseBC, RcsAB \\
\hline Toxins and Bacteriocins & & & $\begin{array}{l}\text { Microcin V, Colicin B, } \\
\text { Colicin M }\end{array}$ & ClyA, Hly III \\
\hline Non-LEE effectors & & $\begin{array}{l}\text { EspL1, EspL4, } \\
\text { EspX1, EspX4, } \\
\text { EspX5, EspR1 }\end{array}$ & & \\
\hline
\end{tabular}

\subsubsection{No Complete Phage Sequences Were Detected in the EC121 Strain}

The search for phage sequences in strain EC121 identified 12 regions containing genes from a variety of different phages, ranging from 6 to $31 \mathrm{~kb}$ (Table 3, Table S5). Although the PHASTER database considered a predicted phage sequence in region 6 as intact, based on their score criteria, its size $(14,400 \mathrm{bp})$ was not compatible with the size of the predicted "enterobacteria phage Fels-2" identified by the algorithm to the region, whose complete genome sequence is 33,693 bp (NCBI database). Remarkably, parts of the cytolethal distending toxin (Cdt-I and Cdt-V), and Shiga-like toxin 
(Stx1a and Stx2c) converting phages, as well as of Shigella serotype-converting phages SfI, SfII, and SfV were detected among these regions (Table 3 and Table S5). However, Stx and Cdt toxin-encoding genes were not identified in strain EC121.

Table 3. Predicted phages detected in the EC121 genome.

\begin{tabular}{lllll}
\hline Region & \multicolumn{1}{c}{ Length } & Completeness ${ }^{\text {a }}$ & Most Common Phage/Accession Number & GC \% \\
\hline 1 & $6.3 \mathrm{~kb}$ & Incomplete & Bacillus phage G/NC_023719 & 51.27 \\
2 & $30.9 \mathrm{~kb}$ & Incomplete & Salmonella phage 118970_sal3/NC_031940 & 49.82 \\
3 & $14.2 \mathrm{~kb}$ & Questionable & Enterobacteria phage P88/NC_026014 & 49.75 \\
4 & $20 \mathrm{~kb}$ & Incomplete & Shigella phage POCJ13/NC_025434 & 47.95 \\
5 & $28.5 \mathrm{~kb}$ & Incomplete & Shigella phage SfII/NC_021857 & 45.37 \\
6 & $14.4 \mathrm{~kb}$ & Intact & Enterobacteria phage Fels-2/NC_010463 & 49.56 \\
7 & $9.4 \mathrm{~kb}$ & Incomplete & Bacillus phage Shanette/NC_028983 & 49.50 \\
8 & $7.5 \mathrm{~kb}$ & Incomplete & Enterobacteria phage phi92/NC_023693 & 44.44 \\
9 & $10.2 \mathrm{~kb}$ & Questionable & Enterobacteria phage P2/NC_001895 & 55.39 \\
10 & $3.8 \mathrm{~kb}$ & Incomplete & Bacteriophage WPhi/NC_005056 & 50.16 \\
11 & $8.4 \mathrm{~kb}$ & Questionable & Phage cdtI/NC_009514 & 46.05 \\
12 & $6.7 \mathrm{~kb}$ & Incomplete & Shewanella sp. phage $\frac{1}{4} /$ NC_025436 & 47.92 \\
\hline
\end{tabular}

a Phage completeness was determined by scores obtained in the search algorithm (PHASTER) based on the number of the phage's specifics CDSs detected in the analyzed region.

3.1.4. EC121 Has Multiple Resistance Genes, and Several Efflux-Pumps Compatible with its Antimicrobial Susceptibility Profile

The software ResFinder identified 15 resistance genes in strain EC121, which are involved in reduced susceptibility to aminoglycosides, $\beta$-lactams, macrolides, phenicols, sulphonamides, trimethoprim, and tetracyclines (Table 4). Mutations in the parE, parC, and in gyrA genes, which confer resistance to fluoroquinolones, were also observed in the EC121 genome. Additionally, several efflux-pumps related to resistance to heavy metals (copper and mercury), arsenic, disinfectants (QacE), and antimicrobials (AcrAB-TolC, AcrAD-TolC, AcrEF-TolC, AcrZ, EmrAB-TolC, EmrD, EmrKY-TolC, MacA, MacB, MdfA/Cmr, MdtABC-TolC, MdtEF-TolC, MdtL, MdtM, and SugE) were detected. The MDR phenotype profile of strain EC121 assessed by the microdilution method was consistent with the genomic findings, as can be seen in Table 4.

Table 4. Antimicrobial resistance genotype and phenotype observed in strain EC121.

\begin{tabular}{|c|c|c|c|}
\hline \multirow{2}{*}{ Antimicrobial Class } & \multirow{2}{*}{ Genotype } & \multicolumn{2}{|l|}{ Phenotype } \\
\hline & & Antimicrobial Agent & $\operatorname{MIC}^{b}(\mu \mathrm{g} / \mathrm{mL})$ \\
\hline \multirow{2}{*}{ Aminoglycosides } & \multirow{2}{*}{$\begin{array}{l}a p h(3 ")-I b, a p h(6)-I d, a p h(4)-I a, \\
a a c(3)-I v a\end{array}$} & amikacin & 2 \\
\hline & & gentamicin & 32 \\
\hline \multirow{9}{*}{$\beta$-lactams } & \multirow{9}{*}{$b l a_{\mathrm{TEM}-1 \mathrm{~B}}, b l a_{\mathrm{CTX}-\mathrm{M}-2}$} & ampicillin & $\geq 256$ \\
\hline & & piperacillin/tazobactam & $>256 / 4$ \\
\hline & & ceftazidime & 64 \\
\hline & & ceftriaxone & $\geq 512$ \\
\hline & & cefepime & 16 \\
\hline & & ertapenem & $\leq 0.5$ \\
\hline & & imipenem & $\leq 0.5$ \\
\hline & & meropenem & $\leq 0.5$ \\
\hline & & aztreonam & $>32$ \\
\hline \multirow{2}{*}{$\begin{array}{l}\text { Sulfonamides/Trimethoprim } \\
\text { Phenicols }\end{array}$} & \multirow{2}{*}{$\begin{array}{l}\text { sul2, sul1, sul1' }{ }^{\prime} \text { dfrA14, dfrA7 } \\
\text { catA1 }\end{array}$} & trimethoprim/sulfamethoxazole & $>128 / 2432$ \\
\hline & & chloramphenicol & $>64$ \\
\hline \multirow{2}{*}{ Tetracyclines } & \multirow{2}{*}{$\operatorname{tet}(A)$} & minocycline & 16 \\
\hline & & tigecycline & 1 \\
\hline Fluoroquinolones & $\begin{array}{l}\operatorname{parE}\left(\mathrm{S}_{458} \mathrm{~A}\right) ; \operatorname{parC}\left(\mathrm{S}_{80} \mathrm{I}\right) ; g y r A \\
\left(\mathrm{~S}_{83} \mathrm{~L} \text { and } \mathrm{D}_{87} \mathrm{Y}\right)\end{array}$ & ciprofloxacin & $>64$ \\
\hline \multirow{2}{*}{ Polymyxins } & \multirow{2}{*}{-} & colistin & $\leq 0.25$ \\
\hline & & polymyxin B & $\leq 0.25$ \\
\hline Fosfomycin & - & fosfomycin & 0.25 \\
\hline Macrolides & $m p h(A), m d f(A)$ & azithromycin & NT \\
\hline
\end{tabular}




\subsubsection{The EC121 Strain Harbors Multiple Plasmids}

Four bands were detected by agarose gel electrophoresis, suggesting that EC121 harbor multiple plasmids (Figure S2). Seven different replicons were found in EC121 using PlasmidFinder (IncHI2A, IncHI2, IncQ1, IncFII, IncFIB, IncN, and IncM1).

Although the EC121 genome is still in draft, we analyzed the replicon containing contigs identified by the PlasmidFinder to provide more information about the strain's plasmid content. A contig of 128,478 bp in length bears both the IncHI2A and IncHI2 replicons. The contig's BLAST showed high identity with the pYps.F1 plasmid of the Yersinia pseudotuberculosis strain Yps.F1 (cover: 99\%, e-value: 0.0, identity: 99.77\%) (Figure S3).

The IncM1 replicon was identified in one contig of $65,565 \mathrm{bp}$ in length, which was circularized in the assembling, and showed high homology (100\% of identity and coverage) with the pASM2 plasmid (accession No. NZ_CP019841.1) of Enterobacter roggenkampii strain R11 (Figure S4).

The other replicons were segregated into four different contigs, with IncFIB and IncFII into contigs of 37,695 and 30,674 bp in length, respectively, and IncN and IncQ1 into contigs with less than $3.5 \mathrm{~kb}$ each.

The IncFIB replicon's contig also contained the virulence genes iroN, iss, and traT as identified in the sequence. The in silico analysis suggested that the plasmid was similar to the pAPEC plasmid that carries virulence and resistance genes simultaneously. Although the IncFII replicon was identified into a different contig, the data indicated that both the IncFII and IncFIB replicons represent segments of the same plasmid. Further studies are required to unravel this plasmid genetic composition.

Conjugation assays were performed to evaluate the presence of conjugative plasmids in EC121. To this purpose, agar plates with different antimicrobial combinations (sodium azide [100 $\mu \mathrm{g} / \mathrm{mL}]$ with gentamycin $[20 \mu \mathrm{g} / \mathrm{mL}]$ or cefotaxime [2 $\mu \mathrm{g} / \mathrm{mL}]$ or chloramphenicol [30 $\mu \mathrm{g} / \mathrm{mL}]$ ) were used to select the transconjugant strains. While no chloramphenicol-resistant transconjugant colony was detected, five transconjugants were recovered from the gentamycin and 20 from the cefotaxime selective agar plates. Thirteen colonies (five from gentamycin and eight from cefotaxime plates) were purified and then investigated regarding their replicon type and presence of virulence genes that are generally located in plasmids ( $h l y F$, sit $A$, and iroN) by PCR. All cefotaxime-resistant transconjugants carried the

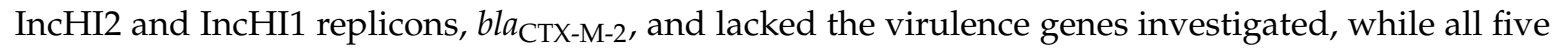
gentamycin-resistant transconjugants carried multiple replicons (IncFIB, IncL/M, IncN, IncHI2, and IncHI1), as well as the $h l y F$, sit $A$, and $i r o N$ genes (Table 5) and the bla $a_{\mathrm{CTX}-\mathrm{M}-2}$ resistance gene. These results suggested that the $b a_{\mathrm{CTX}-\mathrm{M}-2}$ gene was inserted into the IncHI2A/IncHI2 plasmid.

One transconjugant strain of each type was submitted to the microdilution assay to verify the antimicrobial resistance phenotype. E. coli strain ACC09 (E. coli J53 harboring the IncHI2/IncHI2A plasmid) obtained from the cefotaxime agar plate showed ceftriaxone and cotrimoxazole resistance and reduced susceptibility to all beta-lactams (Table 5), whereas E. coli strain ACG04 (E. coli C600 carrying multiple plasmids) showed reduced susceptibility to all the antimicrobials tested, except for ciprofloxacin and tigecycline, and presented increased MIC values to all beta-lactams when compared to ACC09 (Table 5).

Although we isolated only the IncHI2/IncHI2A plasmid, multiple plasmids were transferred efficiently to the receptor strain in a short period of conjugation $(3 \mathrm{~h})$ indicating that all high molecular weight plasmids were conjugative or mobilizable plasmids.

\subsection{Virulence Phenotype}

To evaluate the expression of the virulence-encoding genes detected, in vitro assays were performed to analyze the ability of the strain to (i) resist to the bactericidal activity of the serum complement system; (ii) attach to abiotic surfaces and form biofilms; (iii) adhere to and invade eukaryotic cells. In vivo assays were performed using the G. mellonella infection model to evaluate the EC121 virulence potential. 
Table 5. Resistance profile, replicon type, and virulence genes identified in the EC121's plasmids transferred to E. coli $\mathrm{K}-12$ strains.

\begin{tabular}{|c|c|c|c|c|c|}
\hline Traits & EC121 & $\mathrm{J} 53$ & C600 & ACG04 & ACC09 \\
\hline \multicolumn{6}{|l|}{ Antimicrobial ${ }^{\text {a }}$} \\
\hline ceftazidime & 64 & 0.25 & 0.25 & 8 & 2 \\
\hline ceftriaxone & $\geq 64$ & $\leq 0.125$ & $\leq 0.125$ & $>64$ & $>64$ \\
\hline cefepime & 16 & 0.25 & $\leq 0.125$ & 16 & 2 \\
\hline piperacillin/tazobactam & $>256$ & 2 & 2 & 8 & 2 \\
\hline aztreonam & $>32$ & $\leq 0.125$ & $\leq 0.125$ & 16 & 4 \\
\hline amikacin & 4 & 2 & 2 & 16 & 2 \\
\hline gentamycin & 16 & 0.5 & 0.5 & 32 & 0.5 \\
\hline trimethoprim/sulfamethoxazole & $>128$ & $\leq 0.25$ & $\leq 0.25$ & $>128$ & $>128$ \\
\hline ciprofloxacin & $>64$ & $\leq 0.125$ & $\leq 0.125$ & $\leq 0.125$ & $\leq 0.125$ \\
\hline minocycline & 16 & 1 & 1 & 4 & 1 \\
\hline tigecycline & 1 & 0.25 & 0.125 & 0.25 & 0.125 \\
\hline \multicolumn{6}{|l|}{ Replicon type $^{b}$} \\
\hline IncHI2 & + & - & - & + & + \\
\hline IncL/M & + & - & - & + & - \\
\hline IncFIB & + & - & - & + & - \\
\hline IncN & + & - & - & + & - \\
\hline \multicolumn{6}{|l|}{ Virulence $^{c}$} \\
\hline$h l y F$ & + & - & - & + & - \\
\hline iroN & + & - & - & + & - \\
\hline sitA & + & - & - & + & - \\
\hline \multicolumn{6}{|l|}{ Resistance gene } \\
\hline$b l a_{\text {СТХ-М }}$ & + & - & - & + & + \\
\hline
\end{tabular}

a The antimicrobial resistance phenotype of transconjugant strains was assessed by minimum inhibitory concentration (MIC), performed using the broth microdilution method according to EUCAST guideline, and expressed in $\mu \mathrm{g} / \mathrm{mL}$. Bold values indicate an increased MIC value when comparing strains bearing plasmids with its receptor strain which is devoid of plasmids; ${ }^{b}$ replicons identified in EC121 by PlasmidFinder, and screened by PCR; ${ }^{c}$ virulence genes identified in EC121 genome and screened by PCR; + for the presence of the gene; - for the absence of the gene.

3.2.1. The EC121 Strain Resists the Bactericidal Activity of the Human Complement System and Adheres to Abiotic Surfaces

Extraintestinal pathogenic bacteria must be able to survive the serum bactericidal activity to disseminate in the host. To identify such a feature in EC121, we determined the lowest serum-resistant bacterial inoculum using a pool of normal human sera (NHS). The lowest inoculum of EC121 strain that resisted serum activity after two hours was $10^{2} \mathrm{CFU} / \mathrm{mL}$, which was similar to the inoculum obtained for the resistant control strain J96. E. coli strain C600, used as a susceptible control, barely resisted to a 30 min-exposition period in the highest inoculum tested $\left(10^{8} \mathrm{CFU} / \mathrm{mL}\right)$. To validate that bacterial survival was associated with resistance to complement activity, assays were repeated with heat-inactivated serum. In this condition, all strains survived the challenge with similar inoculum (Table 6).

Table 6. Estimated bacterial inoculum resistant to serum activity $(\mathrm{CFU} / \mathrm{mL}){ }^{a}$

\begin{tabular}{|c|c|c|c|c|c|c|}
\hline \multicolumn{7}{|c|}{ E. coli Strains } \\
\hline \multirow[b]{2}{*}{ Challenge Period } & \multicolumn{2}{|c|}{ J96 } & \multicolumn{2}{|c|}{ EC121 } & \multicolumn{2}{|c|}{ C600 } \\
\hline & NHS & inHS & NHS & inHS & NHS & inHS \\
\hline $30 \mathrm{~min}$ & $10^{1}$ & $10^{1}$ & $10^{2}$ & $10^{1}$ & $10^{8}$ & $10^{1}$ \\
\hline $1 \mathrm{~h}$ & $10^{2}$ & $10^{1}$ & $10^{2}$ & $10^{1}$ & NG & $10^{1}$ \\
\hline $2 \mathrm{~h}$ & $10^{2}$ & $10^{1}$ & $10^{2}$ & $10^{1}$ & NG & $10^{1}$ \\
\hline
\end{tabular}

${ }^{a}$ Values represent the approximate relative mean of the lowest bacterial inoculum that remained viable after the challenge. All assays were performed in triplicate using $50 \%$ serum diluted in phosphate-buffered saline (PBS) (v/v); NHS-Normal human serum; inHS-inactivated human serum; NG—no growth after the challenge.

The ability to adhere to the abiotic surface and form biofilm can confer many advantages to any pathogen, including persistence in particular niches and tolerance against antimicrobials and the host immune system. EC121 strain was able to adhere to borosilicate coverslips and polystyrene when grown in DMEM and TSB, as shown in Figure 4. Although its adherence to the abiotic surface was not massive as the adherence presented by the positive control strain (EAEC 042), it was significantly more intense than that of the negative control strain (HB101) (Figure 4). Furthermore, EC121 produced 
similar $(p>0.05)$ or higher $(p<0.01)$ biofilm masses as the ExPEC prototype strain CFT073 in DMEM and TSB, respectively (Figure $4 b$ ).

A

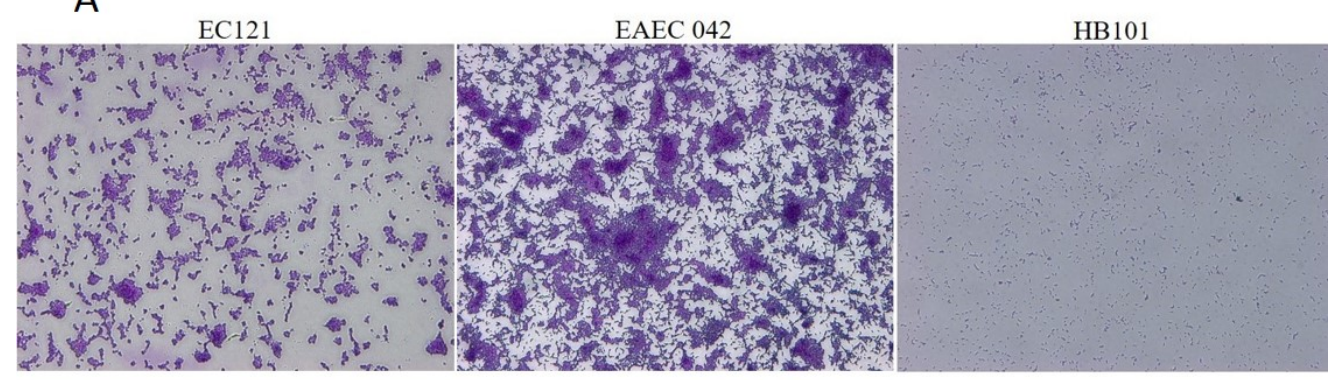

B

DMEM

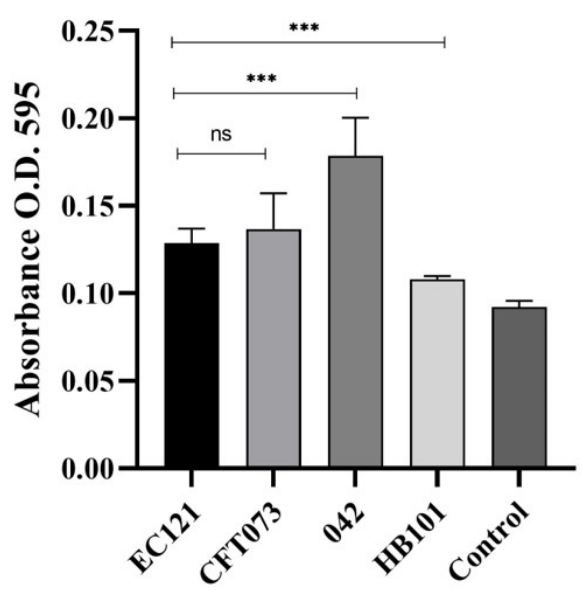

TSB

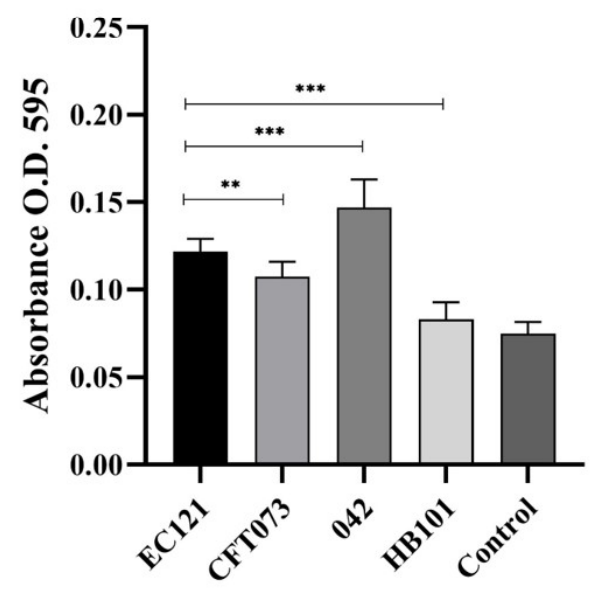

Figure 4. Biofilm formation on borosilicate glass and polystyrene abiotic surfaces. (A) Qualitative assay showing that EC121 strain adhered to glass coverslips after $24 \mathrm{~h}$ of incubation at $37^{\circ} \mathrm{C}$, in DMEM. EAEC prototype strain 042 and E. coli HB101 were used as positive and negative controls, respectively. Bacteria were stained with crystal violet, observed by optical microscopy (OM) 400×. (B) Quantitative biofilm assays were performed in Dulbecco's Modified Eagle's Medium (DMEM) and tryptic soy broth (TSB), at $37^{\circ} \mathrm{C}$, for $24 \mathrm{~h}$, comparing the capacity of strain EC121 to produce biofilm in polystyrene surface. EAEC 042 was used as a positive control, UPEC prototype strain CFT073 was used as an ExPEC control, and Laboratory strain HB101 was used as a negative control. $p$ values: ${ }^{* *}<0.01 ;{ }^{* * *}<0.001$; $\mathrm{ns}>0.05$.

\subsubsection{The EC121 Strain Adheres to and Invades Epithelial Cell Lineages}

At first, we accessed, qualitatively, the ability of strain EC121 to adhere to HeLa, T24, and Caco-2 cells, using a 3-h adherence assay without D-mannose. Strain EC121 interacted efficiently with all cells tested (Figure S5). Subsequently, a quantitative 3-h adherence assay in HeLa cells using an initial inoculum of $1 \times 10^{7}$ was performed in the absence of D-mannose, except for EC121, which was also tested in the presence of $2 \%$ D-mannose. EC121 was able to adhere, both in the presence or absence of D-mannose, which abolishes the adherence mediated by type- 1 fimbriae. However, the presence of D-mannose reduced the adherence ability of strain EC121 significantly, reducing the adherence in about $90 \%$ (Figure 5), from $1.3 \times 10^{7} \mathrm{CFU} / \mathrm{mL}$ to $1.58 \times 10^{6} \mathrm{CFU} / \mathrm{mL}$ (Figure 5). Noteworthy, the EC121 adherence levels in the absence of D-mannose was higher than all controls tested in the same conditions $(p<0.01)$ (Figure 5). 


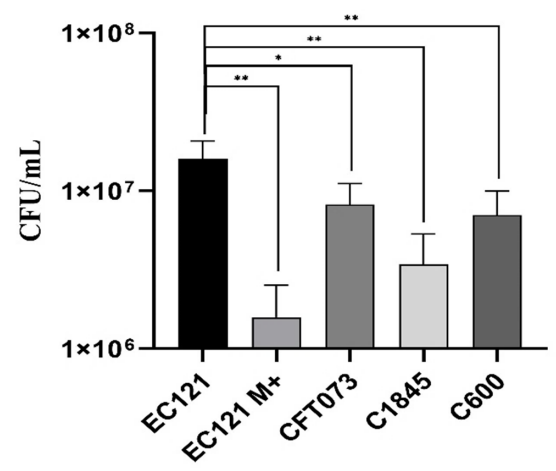

Figure 5. Quantitative adherence assay on HeLa cells. Quantitative assay performed in HeLa cells (3-h of incubation at $37^{\circ} \mathrm{C}$ ) in the absence of D-mannose, except when indicated.; $\mathrm{M}+$, assay performed in the presence of $2 \%$ D-Mannose. The E. coli strains CFT073, C1845, and C600 were used for comparison. Experiments were done in biological duplicates and experimental triplicates. $p$ values: ${ }^{*}<0.05,{ }^{* *}<0.01$.

We also investigated whether the EC121 strain was able to invade T24 and Caco-2 cells. In a short-period invasion assay, the EC121 strain interacted with T24 cells as efficiently as the ExPEC prototype strain CFT073 but invaded this cell lineage significantly more $(p<0.005)$ (Figure 6). On the other hand, its interaction with differentiated and polarized Caco-2 cells was lower when compared with CFT073, although there was no difference related to their capacity to invade this type of cell lineage in the conditions tested.

T24
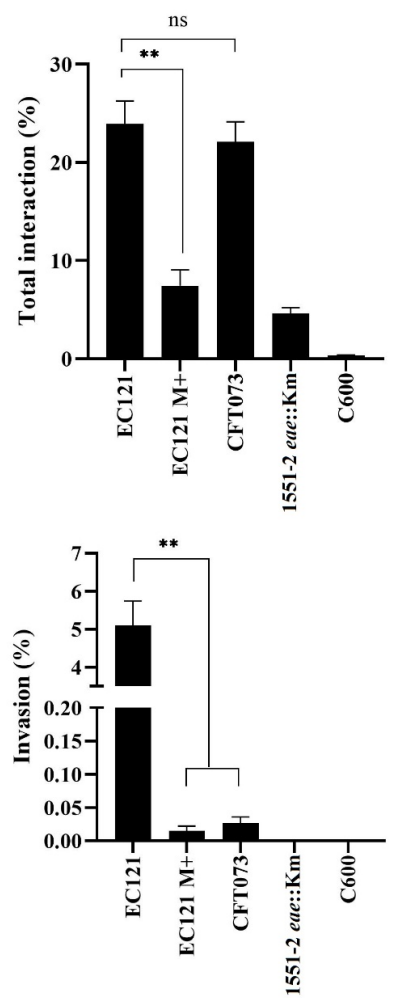

Caco-2
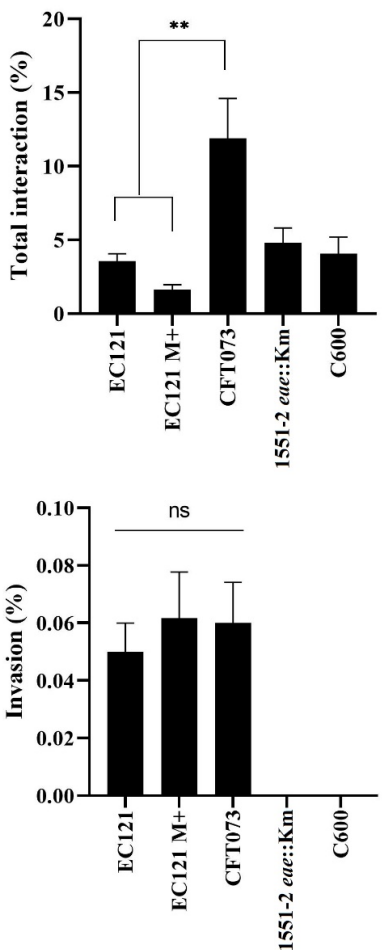

Figure 6. Interaction and invasion in different eukaryotic cell lineages. Short period quantitative invasion assay was performed in Caco- 2 and T24 cells using a multiplicity of infection (MOI) of 50 in confluent cell cultures. All assays were carried out in the absence of D-mannose, except for EC121 $\mathrm{M}+$, where $2 \%$ D-mannose was added in the assay medium; E. coli CFT073 was used as ExPEC control, E. albertti strain 1551-2 eae::Km was used as an adherent noninvasive control, and E. coli C600 as was used as a noninvasive control. The assays were performed in experimental triplicates and biological duplicates. $p$ values: ${ }^{* *}<0.01 ; \mathrm{ns}>0.05$. 
The capacity to interact and invade eukaryotic cells in the presence of D-mannose was also assessed to evaluate whether the interaction and invasion abilities of EC121 were dependent on type-1 fimbriae or another mannose-dependent adhesin. The EC121 interaction with both lineages reduced significantly in the presence of D-mannose, like in HeLa cells, showing that mannose-sensitive adhesins contributed to its capacity to interact with the cell lineages tested. Additionally, EC121 remained invasive in the presence of D-mannose but with reduced bacterial counts in T24 cells $(p<0.003)$. However, there was no difference in the invasiveness in Caco-2 (Figure 6), showing that mannose-sensitive adhesins contributed to both adherence and invasion of EC121, although it was not the only factor associated with these traits.

\subsubsection{EC121 Strain Is Virulent in the Galleria mellonella Virulence Model}

In the G. mellonella virulence model, strain EC121 promoted higher mortality rates than the nonpathogenic E. coli strain C600 ( $p<0.005)$ and the mock-injection $(p<0.0001)$. Although the E. coli strain CFT073 killed more larvae than EC121, there was no significant difference between their survival curves (Figure 7), showing that EC121 is virulent in the model used.

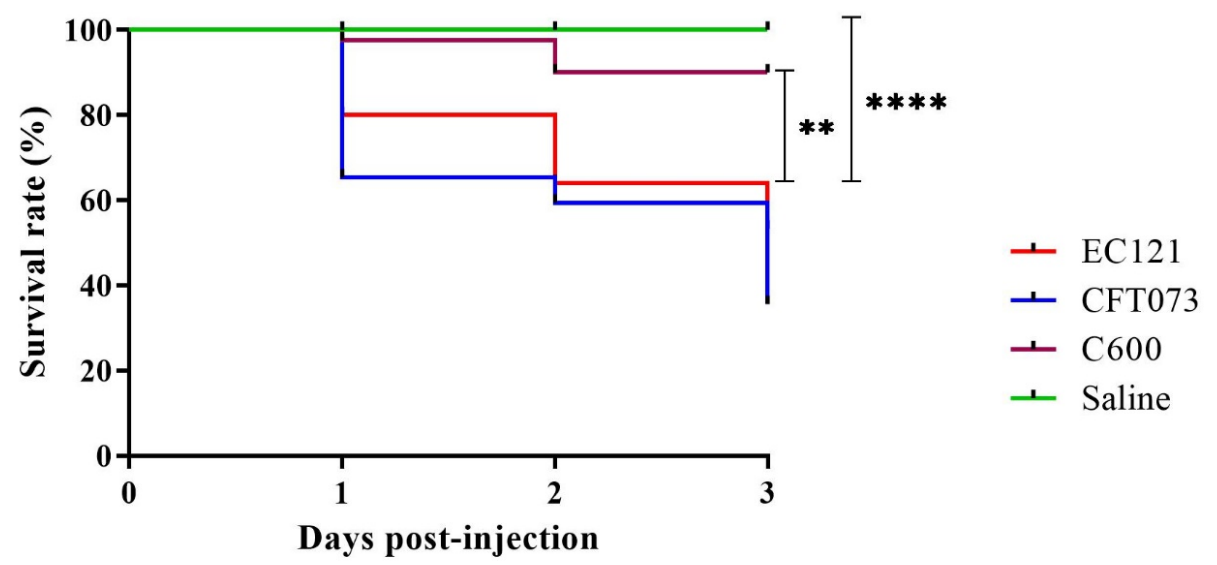

Figure 7. Galleria mellonella infection model. The virulence of EC121 was assessed using an inoculum of $10^{4}$ CFU per G. mellonella larvae. The larvae survival rate, expressed by Kaplan-Meier plots indicated that EC121 was more virulent than the negative control (saline) and the nonpathogenic K-12 derived E. coli C600, while there was no significant difference between the survival rates of EC121 and the ExPEC prototype strain CFT073. $p$-value: $\left.{ }^{* *}<0.005 ;{ }^{* * * *}<0.0001\right)$. The assay was performed three times, with five larvae per group.

\section{Discussion}

EC121 strain was isolated in 2007 from a bloodstream infection of an inpatient that presented persistent gastroenteritis and T-zone lymphoma. Since initial analyses showed that it belonged to phylogenetic group B1 and carried few virulence markers commonly related to extraintestinal pathogenic E. coli, it was classified as ExPEC negative (ExPEC-) [28] and therefore considered as an opportunistic pathogen. However, considering that about $40 \%$ of extraintestinal infections are caused by strains devoid of virulence factors [14,16] and that EC121 was an MDR strain, its genome was sequenced to understand its virulence potential further.

Interestingly, EC121 strain belongs to ST101, which has been previously reported to be involved in nosocomial outbreaks caused by Metallo- $\beta$-lactamases-producing strains in many countries from Europe, Asia, and Oceania [39,40,83-85]. Furthermore, ST101 has also been detected among strains of nonoutbreak related extraintestinal infections [86-93], water [94], poultry infection [95], retail food [86,96-98], and human and animal intestinal microbiota [93,99-102], mostly presenting an MDR phenotype. Shrestha et al. [103] drew attention to ST101 due to the pan drug resistant (PDR) phenotype presented by some strains of this ST, and mainly because it is not considered a pandemic clone, 
although it has been isolated worldwide. We, therefore, analyzed the data about the infection type, isolation source, and resistance genetic markers presented by strains of the ST101 complex that were previously deposited in the NCBI (Table S1). Such analysis evidenced that MDR strains of this complex were spread worldwide. In addition, such ST complex is related to STEC strains as well as strains isolated from extraintestinal infections, human and animal microbiota, retail food, and the environment. Moreover, many strains simultaneously carry the bla $\mathrm{CTX}-\mathrm{M}-55, m c r-1, f o s A 3$, and $q n r S 1$ genes. Interestingly, one strain presents $a a c\left(6^{\prime}\right)-I b-c r, b l a_{\mathrm{CTX}-\mathrm{M}-55}, b l a_{\mathrm{NDM}-5}, b l a_{\mathrm{OXA}-1}, m c r-1$, fos $A 3$, and other 19 resistance genes simultaneously.

Likewise, the EC121 strain showed multiple antimicrobial resistance genes, including genes that confer resistance to third-generation cephalosporins $\left(b l a_{\mathrm{CTX}-\mathrm{M}-2}\right)$. It is worth mentioning that the EC121 strain was isolated in 2007, and its MDR phenotype was relevant since, at that period, EC121 was susceptible only to carbapenems, polymyxins, and amikacin. Recently, the E. coli strain ICBEC72H, which belongs to ST101 and carries only bla $a_{\text {CTX-M-8 }}$ and $m r c-1$ [87], was isolated from a human extraintestinal infection in Brazil. Similarly, the ST101 E. coli strain 200H (Table S1) was isolated from a human urinary tract infection and carried $b l a_{\mathrm{OXA}-9}, m c r-1$, and $a a c\left(6^{\prime}\right)-I b-c r$. These reports show that MDR strains belonging to the ST101 complex have been circulating in Brazil for a long time.

Previous studies showed that the usage of antimicrobial agents in animals selected E. coli strain 912 (ST101) and that it was able to colonize human and pig gut and spread through the environment, reaching and colonizing animals that were not under antimicrobial treatment $[104,105]$. These studies have also shown that ST101 strains can naturally acquire and transfer plasmid-borne antimicrobial resistance genes in the gut $[104,105]$. Such a feature is important for various reasons. First, strain EC121 carried multiple plasmids, which harbored different combinations of antimicrobial-resistance genes, all of which were successfully transferred to E. coli K-12 derived strains in a 3-h conjugation assay. Besides, E. coli strains belonging to ST101 were recovered from retail meat in Europe and Asia [97,98], and from extraintestinal infections in Brazil and the USA in the same regions in which they were detected from retail meat $[86,95]$.

Additionally, strains belonging to the ST101 complex carrying multiple resistance genes were recovered from the intestine of healthy humans and animals in many countries. Therefore, even if these strains do not cause infection directly, they could potentially transfer plasmids to other bacteria, even from distinct genera. Such cross genera plasmid transfer could be easily identified in the plasmids reported in the present study; IncM1 plasmid, for example, is closely related to plasmids found in Klebsiella spp. and Enterobacter spp., while IncHI2/HI2A is related to Salmonella spp. and Yersinia spp. plasmids. Together, these findings reinforce the high risks associated with strains belonging to the ST101 complex due to their ability to colonize the gut of humans and animals, to easily disseminate via retail food and water, and to acquire and spread antimicrobial resistance-encoding genes.

Strains from the ST101 complex are included in the phylogenetic group B1, which implies that they do not have all the classical virulence factors that are usually associated with the most virulent ExPEC strains $[46,47]$. Many studies reported phylogroup B1 E. coli strains as commensals or as intestinal pathogens, but not as extraintestinal pathogens $[46,47,106]$.

The genomic analysis of the EC121 strain showed a high number of virulence genes, demonstrating that it presents all the traits necessary to be considered as an extraintestinal pathogenic agent, like adhesins, iron acquisition systems, and genes related to immune system evasion. Moreover, like other ExPEC strains, EC121 displayed multiple virulence genes related to each feature, reflecting the redundant phenotype that ensures its pathogenicity. However, even considering the completeness of each sequence and each operon, observed by manual checking, the presence of virulence genes per se does not guarantee that they are all expressed. Therefore, to evaluate the expression of such traits, distinct phenotypic assays were performed and confirmed the virulent genetic background of EC121.

To test the bacterial ability to resist the serum complement activity that could be conferred by the presence of traT, iss, and $\operatorname{ompT}$, a two hours challenge assay was performed, in which one particle can traverse the whole circulatory system at least twice. Therefore, a pathogen that resists complement's 
activity during this period, even with a small bacterial load, is, in theory, more capable of reaching different niches and of spreading through the bloodstream or cause a bloodstream infection. EC121 strain resisted the NHS for two hours with an inoculum similar to the resistant E. coli J96 control strain, thus confirming the EC121 serum resistant phenotype. Serum complement is the first immunological barrier to control pathogens that reach the bloodstream. Complement resistance confers bacteria the ability to spread to different body sites through the bloodstream. Hallström et al. [107] reported the relationship of bacterial resistance to NHS with sepsis severity, and other authors have associated it with different kinds of extraintestinal infections [108-110].

The ability to colonize and attach to surfaces is also an important trait for any pathogenic bacteria; in this way, the assays carried out showed not only that EC121 strain was able to adhere to and invade different cell lineages, including bladder T24 cells, but that it could also attach and produce biofilm on abiotic surfaces. Peirano et al. [111] showed that ExPEC-negative ST101 MDR strains isolated from extraintestinal infections could interact with HEp-2 and Caco-2 cells more efficiently than strains belonging to the epidemic clones ST131 and ST405, which are ExPEC positive [111]. Strain EC121 interacted with all cell lineages tested, but its interaction was significantly higher in T24 cells. Besides, its interaction's capacity was similar to the ExPEC prototype strain CFT073, but it invaded T24 cells more efficiently, suggesting that EC121 might be capable of producing intracellular bacterial communities (IBC). IBCs were related to bacterial persistence and recurrent infections in the host [112]. Overall, the EC121 invasiveness might be more related to its persistence ability than to its capacity to transpose epithelial barriers, since persistence may help bacteria to evade the immune system and confer protection against antimicrobial agents. However, further studies are required to prove this hypothesis.

Ten virulence encoding-genes involved with biofilm production were identified in the EC121 genome (Table S3). The capacity to produce biofilm might confer many advantages to bacteria, like protection against the immunological system and antibiotics, assisting its persistence and spreading in the environment. However, biofilm production depends on many factors, like temperature and presence of specific nutrients in the media or environment [113-115]. Moreover, the ability to produce biofilm has been reported to vary among ExPEC strains and strains with this capacity are considered to be more pathogenic [27].

Interestingly, many of the EC121 virulence factors detected in the draft genome are related to diarrheagenic E. coli, even though none of them are implicated in the DEC pathotype definition. The presence of many genetic features related STEC strains, e.g., Hcp, EhaG, and Lpf- $1_{\mathrm{O} 26}$, as well as the proximity of EC121 to the clade that contains STEC strains and the heteropathogenic EAEC/STEC E. coli O104:H4 strain 2011C-3493, draw attention to its potential diarrheagenic background.

Many features identified in the EC121 genome reinforce its linkage with STEC strains. Phenotypically, EC121 expressed the O154:H25 serotype, but it possesses the group IV capsule-encoding genes. This kind of capsular group is known to be thermoresistant and expressed as $\mathrm{K}_{\mathrm{LPS}}$ or O-antigen capsule. This property could explain the expression of the $\mathrm{O} 154$ instead of $\mathrm{O} 100$ antigen, despite the presence of all genes related to the expression of the latter. Interestingly O100 is a STEC related serogroup.

Moreover, much of the phage remains detected in the EC121 strain were related to Stx-converting phages; besides, ST101 strains carrying the $s t x_{1 a}$ gene have been reported in food sources $[96,116]$. In humans, ST101 strains were already reported in a patient with hemolytic uremic syndrome (HUSEC) [116-118] and in nonbloody diarrhea related to a Stx1a-producing E. coli strain [119]. Although only one of these strains had its genome sequenced, some ST101 E. coli strains recovered from animals and food were found to carry stx1. Interestingly, most Stx-converting phages remains found in EC121 were similar to those commonly related to Stx1a production, corroborating the results presented here. The genome of three non-STEC strains from diarrheic patients was found in GenBank, one of which was devoid of DEC virulence factors. Likewise, EC121 was isolated from a bloodstream infection of one inpatient with persistent infectious gastroenteritis, which was probably the source of 
EC121 infection. Unfortunately, the E. coli isolated from stool was not stored, not allowing further comparison between the bloodstream and stool $E$. coli isolates.

Several studies evaluated E. coli pathogenicity in the surrogate G. mellonella model $[15,80,120-123]$. These studies point to the model efficiency in differentiating pathogenic from nonpathogenic strains, especially using a bacterium inoculum of $10^{5} \mathrm{CFU}$ per larvae or lower [15,123]. Moreover, Jønsson et al. [120] have shown that pathogenic $E$. coli needs an inoculum of at least $10^{3} \mathrm{CFU}$ to lead larvae to death. A bacterial inoculum of $1 \times 10^{4} \mathrm{CFU}$ was used to evaluate the EC121 virulence. In the assayed conditions, EC121 was as virulent as the ExPEC prototype strain CFT073, thus corroborating the in silico and in vitro data, showing that some strains from the ST101 are truly pathogenic.

\section{Conclusions}

In summary, our extensive in silico, in vitro, and in vivo analyses of virulence and resistance properties of E. coli strain EC121, an O154:H25 B1-ST101 strain isolated from a human bloodstream infection, confirmed its virulence potential and increased the knowledge on the complex scenario of virulence traits presented in the group of MDR ExPEC-negative E. coli strains, contributing to the potential development of strategies to control the spread of such pathogens.

Supplementary Materials: The following are available online at http://www.mdpi.com/2076-2607/8/6/827/s1, Figure S1: Phylogenetic relationship among 62 human isolates from the ST101 complex; Figure S2: EC121 Plasmid profile; Figure S3: Phylogenetic relationship obtained from sequence alignment to plasmid IncHI2/HI2A, using BLASTn; Figure S4: Phylogenetic relationship obtained from sequence alignment to plasmid IncM1, using BLASTn; Figure S5: EC121 adherence in eukaryotic cell linages HeLa, Caco-2, and T24; Table S1: Escherichia coli ST101 complex strains; Table S2: Type V Secretion system protein identified by MaSyFinder, Table S3: Complete genetic cluster identified in EC121 strain and their predicted association with virulence; Table S4: Virulence genes identification and validation in NCBI and Swiss-Prot; Table S5: Detailed information of all predicted phages detected in strain EC121.

Author Contributions: Conceptualization: A.C.M.S., R.M.S. and T.A.T.G.; data curation: A.C.M.S., R.M.S., M.Y.N.-J., E.C. and T.A.T.G.; formal analysis: A.C.M.S. and E.C.; funding acquisition: R.M.S. and T.A.T.G.; investigation: A.C.M.S., T.B.V., F.F.S., J.F.S.-N., R.C., A.P.S. and C.S.N.; project administration: A.C.M.S., R.M.S. and T.A.T.G.; resources: R.M.S., A.C.G., E.C. and T.A.T.G.; software: A.C.M.S., M.Y.N.-J. and E.C.; supervision: A.C.M.S., R.C., R.M.S. and T.A.T.G.; validation: A.C.M.S., T.B.V., F.F.S., J.F.S.-N., A.P.S., C.S.N. and E.C.; visualization: A.C.M.S.; writing-original draft preparation: A.C.M.S., R.M.S. and T.A.T.G.; writing-review and editing: All authors reviewed the original draft and critically contributed to the writing of the final version. All authors have read and agreed to the published version of the manuscript.

Funding: This study was supported by Fundação de Amparo à Pesquisa do Estado de São Paulo (FAPESP) that provided research grants to E.C. (Process Number: 16/01656-5), R.M.S. (Process Number: 2009/00402-6), T.A.T.G. (Process Number: 2018/17353-7), and master scholarship to T.B.V. (Process Number: 2017/21947-7). We are also grateful to the Coordenação de Aperfeiçoamento de Pessoal de Nível Superior (CAPES) for providing grants under finance code 001 to A.C.M.S. (PNPD: 88882.306532/2018-01), A.P.S. (Ph.D. scholarship), C.S.N. (Ph.D. scholarship), and to the National Council for Science and Technological Development (CNPq) for providing a grant to A.C.G. (Process number: 305535/2014-5). The funding agencies had no role in the design, execution, interpretation, or writing of the study.

Conflicts of Interest: A.C.G. has recently received research funding and/or consultation fees from Eurofarma, MSD, Pfizer, and Zambon. This study was not financially supported by any diagnostic/pharmaceutical company. Other authors declare no conflict of interest.

\section{References}

1. Biedenbach, D.J.; Moet, G.J.; Jones, R.N. Occurrence and antimicrobial resistance pattern comparisons among bloodstream infection isolates from the SENTRY Antimicrobial Surveillance Program (1997-2002). Diagn. Microbiol. Infect. Dis. 2004, 50, 59-69. [CrossRef] [PubMed]

2. Temkin, E.; Fallach, N.; Almagor, J.; Gladstone, B.P.; Tacconelli, E.; Carmeli, Y. DRIVE-AB Consortium Estimating the number of infections caused by antibiotic-resistant Escherichia coli and Klebsiella pneumoniae in 2014: A modelling study. Lancet. Glob. Heal. 2018, 6, e969-e979. [CrossRef]

3. Tu, B.; Liu, S.X.; Wu, D.; Zhang, X.; Shi, L.; Xie, Y.X.; Zhao, P.; Qin, E.Q. Clinical features of community-acquired bloodstream infection due to Gram-negative bacilli in patients with liver cirrhosis. Zhonghua Gan Zang Bing Za Zhi 2018, 26, 23-27. [CrossRef] [PubMed] 
4. Satwani, P.; Freedman, J.L.; Chaudhury, S.; Jin, Z.; Levinson, A.; Foca, M.D.; Krajewski, J.; Sahdev, I.; Talekar, M.K.; Gardenswartz, A.; et al. A Multicenter Study of Bacterial Blood Stream Infections in Pediatric Allogeneic Hematopoietic Cell Transplantation Recipients: The Role of Acute Gastrointestinal Graft-versus-Host Disease. Biol. Blood Marrow Transplant. 2017, 23, 642-647. [CrossRef]

5. Nivesvivat, T.; Piyaraj, P.; Thunyaharn, S.; Watanaveeradej, V.; Suwanpakdee, D. Clinical epidemiology, risk factors and treatment outcomes of extended-spectrum beta-lactamase producing Enterobacteriaceae bacteremia among children in a Tertiary Care Hospital, Bangkok, Thailand. BMC Res. Notes 2018, 11, 624. [CrossRef] [PubMed]

6. World Health Organization GLASS. Global Antimicrobial Resistance Surveillance System (GLASS) Report; WHO: Geneva, Switzerland, 2018; Available online: https://www.who.int/glass/resources/publications/earlyimplementation-report/en/ (accessed on 17 June 2019).

7. Landman, W.J.M.; van Eck, J.H.H. The incidence and economic impact of the Escherichia coli peritonitis syndrome in Dutch poultry farming. Avian. Pathol. 2015, 44, 370-378. [CrossRef] [PubMed]

8. Kaye, K.S.; Marchaim, D.; Chen, T.-Y.; Baures, T.; Anderson, D.J.; Choi, Y.; Sloane, R.; Schmader, K.E. Effect of Nosocomial Bloodstream Infections on Mortality, Length of Stay, and Hospital Costs in Older Adults. J. Am. Geriatr. Soc. 2014, 62, 306-311. [CrossRef]

9. Barriere, S.L. Clinical, economic and societal impact of antibiotic resistance. Expert Opin. Pharmacother. 2015, 16, 151-153. [CrossRef]

10. Ciorba, V.; Odone, A.; Veronesi, L.; Pasquarella, C.; Signorelli, C. Antibiotic resistance as a major public health concern: Epidemiology and economic impact. Ann. Ig. 2015, 27, 562-579. [CrossRef] [PubMed]

11. Johnson, J.R.; Russo, T.A. Extraintestinal pathogenic Escherichia coli: “The other bad E. coli.". J. Lab. Clin. Med. 2002, 139, 155-162. [CrossRef]

12. Johnson, J.R.; Russo, T.A. Molecular Epidemiology of Extraintestinal Pathogenic Escherichia coli. EcoSal Plus 2018, 8. [CrossRef] [PubMed]

13. Johnson, J.R.; Murray, A.C.; Gajewski, A.; Sullivan, M.; Snippes, P.; Kuskowski, M.A.; Smith, K.E. Isolation and molecular characterization of nalidixic acid-resistant extraintestinal pathogenic Escherichia coli from retail chicken products. Antimicrob. Agents Chemother. 2003, 47, 2161-2168. [CrossRef] [PubMed]

14. Spurbeck, R.R.; Dinh, P.C.; Walk, S.T.; Stapleton, A.E.; Hooton, T.M.; Nolan, L.K.; Kim, K.S.; Johnson, J.R.; Mobley, H.L.T. Escherichia coli Isolates That Carry vat, fyuA, chuA, and $y f_{c} V$ Efficiently Colonize the Urinary Tract. Infect. Immun. 2012, 80, 4115-4122. [CrossRef] [PubMed]

15. Williamson, D.A.; Mills, G.; Johnson, J.R.; Porter, S.; Wiles, S. In vivo correlates of molecularly inferred virulence among extraintestinal pathogenic Escherichia coli (ExPEC) in the wax moth Galleria mellonella model system. Virulence 2014, 5, 388-393. [CrossRef] [PubMed]

16. Santos, A.C.M.; Zidko, A.C.M.; Pignatari, A.C.; Silva, R.M. Assessing the diversity of the virulence potential of Escherichia coli isolated from bacteremia in São Paulo, Brazil. Brazilian J. Med. Biol. Res. 2013, 46, 968-973. [CrossRef]

17. Leimbach, A.; Hacker, J.; Dobrindt, U.E. E. coli as an all-rounder: The thin line between commensalism and pathogenicity. Curr. Top. Microbiol. Immunol. 2013, 358, 3-32. [CrossRef]

18. Wang, Y.; Kim, K.S. Role of OmpA and IbeB in Escherichia coli K1 Invasion of Brain Microvascular Endothelial Cells In Vitro and In Vivo. Pediatr. Res. 2002, 51, 559-563. [CrossRef]

19. Huang, S.H.; Chen, Y.H.; Fu, Q.; Stins, M.; Wang, Y.; Wass, C.; Kim, K.S. Identification and characterization of an Escherichia coli invasion gene locus, ibeB, required for penetration of brain microvascular endothelial cells. Infect. Immun. 1999, 67, 2103-2109. [CrossRef]

20. Mitra, A.; Palaniyandi, S.; Herren, C.D.; Zhu, X.; Mukhopadhyay, S. Pleiotropic Roles of uvrY on Biofilm Formation, Motility and Virulence in Uropathogenic Escherichia coli CFT073. PLoS ONE 2013, 8, e55492. [CrossRef]

21. Kim, W.J.; Shea, A.E.; Kim, J.H.; Daaka, Y. Uropathogenic Escherichia coli invades bladder epithelial cells by activating kinase networks in host cells. J. Biol. Chem. 2018, 293, 16518-16527. [CrossRef]

22. Kondratyeva, K.; Wollman, A.; Gerlitz, G.; Navon-Venezia, S. Adhesion and invasion to epithelial cells and motility of extended-spectrum $\beta$-lactamase-producing Escherichia coli reveal st131 superiority: A comparative in vitro study of extraintestinal pathogenic E. coli lineages. J. Med. Microbiol. 2017, 66, 1350-1357. [CrossRef] [PubMed] 
23. Saldaña, Z.; De La Cruz, M.A.; Carrillo-Casas, E.M.; Durán, L.; Zhang, Y.; Hernández-Castro, R.; Puente, J.L.; Daaka, Y.; Girón, J.A. Production of the Escherichia coli common pilus by uropathogenic E. coli is associated with adherence to HeLa and HTB-4 cells and invasion of mouse bladder urothelium. PLoS ONE 2014, 9. [CrossRef] [PubMed]

24. Johnson, J.R. Microbial virulence determinants and the pathogenesis of urinary tract infection. Infect. Dis. Clin. N. Am. 2003, 17, 261-278. [CrossRef]

25. Buckles, E.L.; Wang, X.; Lane, M.C.; Lockatell, C.V.; Johnson, D.E.; Rasko, D.A.; Mobley, H.L.T.; Donnenberg, M.S. Role of the K2 Capsule in Escherichia coli Urinary Tract Infection and Serum Resistance. J. Infect. Dis. 2009, 199, 1689-1697. [CrossRef] [PubMed]

26. Miyazaki, J.; Ba-Thein, W.; Kumao, T.; Obata Yasuoka, M.; Akaza, H.; Hayshi, H. Type 1, P and S fimbriae, and afimbrial adhesin I are not essential for uropathogenic Escherichia coli to adhere to and invade bladder epithelial cells. FEMS Immunol. Med. Microbiol. 2002, 33, 23-26. [CrossRef] [PubMed]

27. Mittal, S.; Sharma, M.; Chaudhary, U. Biofilm and multidrug resistance in uropathogenic Escherichia coli. Pathog. Glob. Health 2015, 109, 26-29. [CrossRef] [PubMed]

28. Santos, A.C.M. Potencial de virulência e suscetibilidade a antimicrobianos de amostras de Escherichia coli isoladas de bacteremia. Sua relação com o estado de imunocompetência do paciente e a origem da infecção. Ph.D Thesis, Universidade Federal de São Paulo (UNIFESP), São Paulo, Brazil, 2013.

29. Landraud, L.; Jauréguy, F.; Frapy, E.; Guigon, G.; Gouriou, S.; Carbonnelle, E.; Clermont, O.; Denamur, E.; Picard, B.; Lemichez, E.; et al. Severity of Escherichia coli bacteraemia is independent of the intrinsic virulence of the strains assessed in a mouse model. Clin. Microbiol. Infect. 2013, 19, 85-90. [CrossRef]

30. Zhao, L.; Zhang, J.; Zheng, B.; Wei, Z.; Shen, P.; Li, S.; Li, L.; Xiao, Y. Molecular epidemiology and genetic diversity of fluoroquinolone-resistant Escherichia coli isolates from patients with community-onset infections in 30 Chinese county hospitals. J. Clin. Microbiol. 2015, 53, 766-770. [CrossRef]

31. Izdebski, R.; Baraniak, A.; Herda, M.; Fiett, J.; Bonten, M.J.M.; Carmeli, Y.; Goossens, H.; Hryniewicz, W.; Brun-buisson, C.; Gniadkowski, M.; et al. MLST reveals potentially high-risk international clones of Enterobacter cloacae. J. Antimicrob. Chemother. 2015, 70, 48-56. [CrossRef]

32. Brauner, J.; Hallin, M.; Deplano, A.; Mendonça, R.; Nonhoff, C.; Ryck, R.; Roisin, S.; Struelens, M.J.; Denis, O. Community-acquired methicillin-resistant Staphylococcus aureus clones circulating in Belgium from 2005 to 2009: Changing epidemiology. Eur. J. Clin. Microbiol. Infect. Dis. 2013, 32, 613-620. [CrossRef]

33. Riley, L.W. Pandemic lineages of extraintestinal pathogenic Escherichia coli. Clin. Microbiol. Infect. 2014, 20, 380-390. [CrossRef]

34. Roer, L.; Overballe-Petersen, S.; Hansen, F.; Schønning, K.; Wang, M.; Røder, B.L.; Hansen, D.S.; Justesen, U.S.; Andersen, L.P.; Fulgsang-Damgaard, D.; et al. Escherichia coli Sequence Type 410 Is Causing New International High-Risk Clones. mSphere 2018, 3, e00337-18. [CrossRef]

35. Reineke, K.; Sevenich, R.; Hertwig, C.; Janßen, T.; Fröhling, A.; Knorr, D.; Wieler, L.H.; Schlüter, O. Comparative study on the high pressure inactivation behavior of the Shiga toxin-producing Escherichia coli O104:H4 and O157:H7 outbreak strains and a non-pathogenic surrogate. Food Microbiol. 2015, 46, 184-194. [CrossRef] [PubMed]

36. Kennedy, C.A.; Walsh, C.; Karczmarczyk, M.; O’Brien, S.; Akasheh, N.; Quirke, M.; Farrell-Ward, S.; Buckley, T.; Fogherty, U.; Kavanagh, K.; et al. Multi-drug resistant Escherichia coli in diarrhoeagenic foals: Pulsotyping, phylotyping, serotyping, antibiotic resistance and virulence profiling. Vet. Microbiol. 2018, 223, 144-152. [CrossRef] [PubMed]

37. World Health Organization WHO. Global Action Plan on Antimicrobial Resistance; WHO: Geneva, Switzerland, 201720 June; Available online: https:/www.who.int/antimicrobial-resistance/publications/global-actionplan/en/ (accessed on 17 June 2019).

38. Shaik, S.; Ranjan, A.; Tiwari, S.K.; Hussain, A.; Nandanwar, N.; Kumar, N.; Jadhav, S.; Semmler, T.; Baddam, R.; Islam, M.A.; et al. Comparative Genomic Analysis of Globally Dominant ST131 Clone with Other Epidemiologically Successful Extraintestinal Pathogenic Escherichia coli (ExPEC) Lineages. MBio 2017, 8, e01596-17. [CrossRef] [PubMed]

39. Ranjan, A.; Shaik, S.; Mondal, A.; Nandanwar, N.; Hussain, A.; Semmler, T.; Kumar, N.; Tiwari, S.K.; Jadhav, S.; Wieler, L.H.; et al. Molecular Epidemiology and Genome Dynamics of New Delhi Metallo- $\beta$-Lactamase-Producing Extraintestinal Pathogenic Escherichia coli Strains from India. Antimicrob. Agents Chemother. 2016, 60, 6795-6805. [CrossRef] [PubMed] 
40. Poirel, L.; Savov, E.; Nazli, A.; Trifonova, A.; Todorova, I.; Gergova, I.; Nordmann, P. Outbreak caused by NDM-1- and RmtB-producing Escherichia coli in Bulgaria. Antimicrob. Agents Chemother. 2014, 58, 2472-2474. [CrossRef]

41. Mora, A.; Blanco, M.; López, C.; Mamani, R.; Blanco, J.E.J.; Alonso, M.P.; García-Garrote, F.; Dahbi, G.; Herrera, A.; Fernández, A.; et al. Emergence of clonal groups O1:HNM-D-ST59, O15:H1-D-ST393, O20:H34/HNM-D-ST354, O25b:H4-B2-ST131 and ONT:H21,42-B1-ST101 among CTX-M-14-producing Escherichia coli clinical isolates in Galicia, northwest Spain. Int. J. Antimicrob. Agents 2011, 37, $16-21$. [CrossRef]

42. Manges, A.R.; Geum, H.M.; Guo, A.; Edens, T.J.; Fibke, C.D.; Pitout, J.D.D. Global extraintestinal pathogenic Escherichia coli (Expec) lineages. Clin. Microbiol. Rev. 2019, 32. [CrossRef]

43. World Health Organization WHO. No Time to Wait: Securing the Future from Drug-Resistant Infections; WHO: Geneva, Switzerland, 2019. Available online: https://www.who.int/antimicrobial-resistance/interagencycoordination-group/final-report/en/ (accessed on 27 June 2019).

44. Magiorakos, A.-P.; Srinivasan, A.; Carey, R.B.; Carmeli, Y.; Falagas, M.E.; Giske, C.G.; Harbarth, S.; Hindler, J.F.; Kahlmeter, G.; Olsson-Liljequist, B.; et al. Multidrug-resistant, extensively drug-resistant and pandrug-resistant bacteria: An international expert proposal for interim standard definitions for acquired resistance. Clin. Microbiol. Infect. 2012, 18, 268-281. [CrossRef]

45. Calvert, M.B.; Jumde, V.R.; Titz, A. Pathoblockers or antivirulence drugs as a new option for the treatment of bacterial infections. Beilstein J. Org. Chem. 2018, 14, 2607-2617. [CrossRef] [PubMed]

46. Picard, B.; Garcia, J.S.; Gouriou, S.; Duriez, P.; Brahimi, N.; Bingen, E.; Elion, J.; Denamur, E. The link between phylogeny and virulence in Escherichia coli extraintestinal infection. Infect. Immun. 1999, 67, 546-553. [CrossRef] [PubMed]

47. Johnson, J.R.; Clermont, O.; Menard, M.; Kuskowski, M.A.; Picard, B.; Denamur, E. Experimental Mouse Lethality of Escherichia coli Isolates, in Relation to Accessory Traits, Phylogenetic Group, and Ecological Source. J. Infect. Dis. 2006, 194, 1141-1150. [CrossRef] [PubMed]

48. Massot, M.; Daubié, A.-S.; Clermont, O.; Jauréguy, F.; Couffignal, C.; Dahbi, G.; Mora, A.; Blanco, J.; Branger, C.; Mentré, F.; et al. Phylogenetic, virulence and antibiotic resistance characteristics of commensal strain populations of Escherichia coli from community subjects in the Paris area in 2010 and evolution over 30 years. Microbiology 2016, 162, 642-650. [CrossRef]

49. Sabaté, M.; Moreno, E.; Pérez, T.; Andreu, A.; Prats, G. Pathogenicity island markers in commensal and uropathogenic Escherichia coli isolates. Clin. Microbiol. Infect. 2006, 12, 880-886. [CrossRef]

50. Bankevich, A.; Nurk, S.; Antipov, D.; Gurevich, A.A.; Dvorkin, M.; Kulikov, A.S.; Lesin, V.M.; Nikolenko, S.I.; Pham, S.; Prjibelski, A.D.; et al. SPAdes: A New Genome Assembly Algorithm and Its Applications to Single-Cell Sequencing. J. Comput. Biol. 2012, 19, 455-477. [CrossRef]

51. Krawczyk, P.S.; Lipinski, L.; Dziembowski, A. PlasFlow: Predicting plasmid sequences in metagenomic data using genome signatures. Nucleic Acids Res. 2018, 46, e35. [CrossRef]

52. Larsen, M.V.; Cosentino, S.; Rasmussen, S.; Friis, C.; Hasman, H.; Marvig, R.L.; Jelsbak, L.; Sicheritz-Ponten, T.; Ussery, D.W.; Aarestrup, F.M.; et al. Multilocus Sequence Typing of Total-Genome-Sequenced Bacteria. J. Clin. Microbiol. 2012, 50, 1355-1361. [CrossRef]

53. Joensen, K.G.; Tetzschner, A.M.M.; Iguchi, A.; Aarestrup, F.M.; Scheutz, F. Rapid and easy in silico serotyping of Escherichia coli isolates by use of whole-genome sequencing data. J. Clin. Microbiol. 2015, 53, 2410-2426. [CrossRef]

54. Carattoli, A.; Zankari, E.; García-Fernández, A.; Voldby Larsen, M.; Lund, O.; Villa, L.; Møller Aarestrup, F.; Hasman, H. In Silico Detection and Typing of Plasmids using PlasmidFinder and Plasmid Multilocus Sequence Typing. Antimicrob. Agents Chemother. 2014, 58, 3895-3903. [CrossRef]

55. Zankari, E.; Hasman, H.; Cosentino, S.; Vestergaard, M.; Rasmussen, S.; Lund, O.; Aarestrup, F.M.; Larsen, M.V. Identification of acquired antimicrobial resistance genes. J. Antimicrob. Chemother. 2012, 67, 2640-2644. [CrossRef] [PubMed]

56. Joensen, K.G.; Scheutz, F.; Lund, O.; Hasman, H.; Kaas, R.S.; Nielsen, E.M.; Aarestrup, F.M. Real-time whole-genome sequencing for routine typing, surveillance, and outbreak detection of verotoxigenic Escherichia coli. J. Clin. Microbiol. 2014, 52, 1501-1510. [CrossRef] [PubMed]

57. Arndt, D.; Grant, J.R.; Marcu, A.; Sajed, T.; Pon, A.; Liang, Y.; Wishart, D.S. PHASTER: A better, faster version of the PHAST phage search tool. Nucleic Acids Res. 2016, 44, W16-W21. [CrossRef] [PubMed] 
58. Zhou, Y.; Liang, Y.; Lynch, K.H.; Dennis, J.J.; Wishart, D.S. PHAST: A Fast Phage Search Tool. Nucleic Acids Res. 2011, 39, W347-W352. [CrossRef]

59. Wattam, A.R.; Davis, J.J.; Assaf, R.; Boisvert, S.; Brettin, T.; Bun, C.; Conrad, N.; Dietrich, E.M.; Disz, T.; Gabbard, J.L.; et al. Improvements to PATRIC, the all-bacterial Bioinformatics Database and Analysis Resource Center. Nucleic Acids Res. 2017, 45, D535-D542. [CrossRef]

60. Altschul, S.; Madden, T.L.; Schäffer, A.A.; Zhang, J.; Zhang, Z.; Miller, W.; Lipman, D.J. Gapped BLAST and PSI-BLAST: A new generation of protein database search programs. Nucleic Acids Res. 1997, 25, 3389-3402. [CrossRef]

61. Bateman, A. UniProt: A worldwide hub of protein knowledge. Nucleic Acids Res. 2019, 47, D506-D515. [CrossRef]

62. Letunic, I.; Bork, P. Interactive Tree Of Life (iTOL) v4: Recent updates and new developments. Nucleic Acids Res. 2019, 47, W256-W259. [CrossRef]

63. Mareuil, F.; Doppelt-Azeroual, O.; Ménager, H.; Mareuil, F.; Doppelt-Azeroual, O.; Ménager, H. A public Galaxy platform at Pasteur used as an execution engine for web services. F1000Research 2017, 6. [CrossRef]

64. Abby, S.S.; Néron, B.; Ménager, H.; Touchon, M.; Rocha, E.P.C. MacSyFinder: A Program to Mine Genomes for Molecular Systems with an Application to CRISPR-Cas Systems. PLoS ONE 2014, 9, e110726. [CrossRef]

65. Abby, S.S.; Cury, J.; Guglielmini, J.; Néron, B.; Touchon, M.; Rocha, E.P.C. Identification of protein secretion systems in bacterial genomes. Sci. Rep. 2016, 6, 23080. [CrossRef] [PubMed]

66. Orskov, F.; Orskov, I. Escherichia coli O:H serotypes isolated from human blood. Prevalence of the K1 antigen with technical details of $\mathrm{O}$ and $\mathrm{H}$ antigenic determination. Acta Pathol. Microbiol. Scand. Suppl. 1975, 83, 595-600. [PubMed]

67. EUCAST The European Committee on Antimicrobial Susceptibility Testing. Breakpoint Tables for Interpretation of MICs and Zone Diameters Version 9.0. 2019. Available online: http://www.eucast.org (accessed on 20 June 2019).

68. Birnboim, H.C.; Doly, J. A rapid alkaline extraction procedure for screening recombinant plasmid DNA. Nucleic Acids Res. 1979, 7, 1513-1523. [CrossRef] [PubMed]

69. Moran, R.A.; Anantham, S.; Hall, R.M. An improved plasmid size standard, 39R861+. Plasmid 2019, 102, 6-9. [CrossRef] [PubMed]

70. Meyers, J.A.; Sanchez, D.; Elwell, L.P.; Falkow, S. Simple Agarose Gel Electrophoretic Method for the Identification and Characterization of Plasmid Deoxyribonucleic Acid. J. Bacteriol. 1976, 127, 1529-1537. [CrossRef]

71. Matsumura, Y.; Peirano, G.; Pitout, J.D.D. Complete genome sequence of Escherichia coli J53, an azide-resistant laboratory strain used for conjugation experiments. Genome Announc. 2018, 6. [CrossRef]

72. Allué-Guardia, A.; Nyong, E.C.; Koenig, S.S.K.; Vargas, S.M.; Bono, J.L.; Eppinger, M. Closed Genome Sequence of Escherichia coli K-12 Group Strain C600. Microbiol. Resour. Announc. 2019, 8. [CrossRef] [PubMed]

73. Lima, M.P.; Yamamoto, D.; de Mello Santos, A.C.; Ooka, T.; Hernandes, R.T.; Vieira, M.A.M.; Santos, F.F.; Silva, R.M.; Hayashi, T.; Gomes, T.A.T. Phenotypic characterization and virulence-related properties of Escherichia albertii strains isolated from children with diarrhea in Brazil. Pathog. Dis. 2019, 77. [CrossRef] [PubMed]

74. Carattoli, A.; Bertini, A.; Villa, L.; Falbo, V.; Hopkins, K.L.; Threlfall, E.J. Identification of plasmids by PCR-based replicon typing. J. Microbiol. Methods 2005, 63, 219-228. [CrossRef] [PubMed]

75. Houdouin, V.; Bonacorsi, S.; Brahimi, N.; Clermont, O.; Nassif, X.; Bingen, E. A uropathogenicity island contributes to the pathogenicity of Escherichia coli strains that cause neonatal meningitis. Infect. Immun. 2002, 70, 5865-5869. [CrossRef]

76. Garcia, B.G.; Ooka, T.; Gotoh, Y.; Vieira, M.A.M.; Yamamoto, D.; Ogura, Y.; Girão, D.M.; Sampaio, S.C.F.; Melo, A.B.; Irino, K.; et al. Genetic relatedness and virulence properties of enteropathogenic Escherichia coli strains of serotype O119:H6 expressing localized adherence or localized and aggregative adherence-like patterns on HeLa cells. Int. J. Med. Microbiol. 2016, 306, 152-164. [CrossRef] [PubMed]

77. Santos, F.F.; Yamamoto, D.; Abe, C.M.; Bryant, J.A.; Hernandes, R.T.; Kitamura, F.C.; Castro, F.S.; Valiatti, T.B.; Piazza, R.M.F.; Elias, W.P.; et al. The Type III Secretion System (T3SS)-Translocon of Atypical Enteropathogenic Escherichia coli (aEPEC) Can Mediate Adherence. Front. Microbiol. 2019, 10. [CrossRef] [PubMed] 
78. Martinez, J.J.; Mulvey, M.A.; Schilling, J.D.; Pinkner, J.S.; Hultgren, S.J. Type 1 pilus-mediated bacterial invasion of bladder epithelial cells. EMBO J. 2000, 19, 2803-2812. [CrossRef] [PubMed]

79. Hernandes, R.T.; Silva, R.M.; Carneiro, S.M.; Salvador, F.A.; Fernandes, M.C.D.C.; Padovan, A.C.B.; Yamamoto, D.; Mortara, R.A.; Elias, W.P.; da Silva Briones, M.R.; et al. The localized adherence pattern of an atypical enteropathogenic Escherichia coli is mediated by intimin omicron and unexpectedly promotes HeLa cell invasion. Cell. Microbiol. 2008, 0. [CrossRef] [PubMed]

80. Alghoribi, M.F.; Gibreel, T.M.; Dodgson, A.R.; Beatson, S.A.; Upton, M. Galleria mellonella Infection Model Demonstrates High Lethality of ST69 and ST127 Uropathogenic E. coli. PLoS ONE 2014, 9, e101547. [CrossRef] [PubMed]

81. Andrey, D.O.; Pereira Dantas, P.; Martins, W.B.S.; Marques De Carvalho, F.; Gonzaga, L.; Almeida, P.; Sands, K.; Portal, E.; Sauser, J.; Cayô, R.; et al. An Emerging Clone, Klebsiella pneumoniae Carbapenemase 2-Producing K. pneumoniae Sequence Type 16, Associated With High Mortality Rates in a CC258-Endemic Setting. Clin. Infect. Dis. 2019. [CrossRef] [PubMed]

82. Beghain, J.; Bridier-Nahmias, A.; Nagard, H.L.; Denamur, E.; Clermont, O. ClermonTyping: An easy-to-use and accurate in silico method for Escherichia genus strain phylotyping. Microb. Genom. 2018, 4, e000192. [CrossRef]

83. Pfeifer, Y.; Trifonova, A.; Pietsch, M.; Brunner, M.; Todorova, I.; Gergova, I.; Wilharm, G.; Werner, G.; Savov, E. Clonal Transmission of Gram-Negative Bacteria with Carbapenemases NDM-1, VIM-1, and OXA-23/72 in a Bulgarian Hospital. Microb. Drug Resist. 2017, 23, 301-307. [CrossRef] [PubMed]

84. Poirel, L.; Lagrutta, E.; Taylor, P.; Pham, J.; Nordmann, P. Emergence of metallo- $\beta$-lactamase NDM-1-producing multidrug-resistant Escherichia coli in Australia. Antimicrob. Agents Chemother. 2010, 54, 4914-4916. [CrossRef] [PubMed]

85. Yoo, J.S.; Kim, H.M.; Koo, H.S.; Yang, J.W.; Yoo, J.I.; Kim, H.S.; Park, H.K.; Lee, Y.S. Nosocomial transmission of NDM-1-producing Escherichia coli ST101 in a Korean hospital. J. Antimicrob. Chemother. 2013, 68, 2170-2172. [CrossRef] [PubMed]

86. Yamaji, R.; Friedman, C.R.; Rubin, J.; Suh, J.; Thys, E.; McDermott, P.; Hung-Fan, M.; Riley, L.W. A Population-Based Surveillance Study of Shared Genotypes of Escherichia coli Isolates from Retail Meat and Suspected Cases of Urinary Tract Infections. mSphere 2018, 3, e00179-18. [CrossRef] [PubMed]

87. Fernandes, M.R.; McCulloch, J.A.; Vianello, M.A.; Moura, Q.; Pérez-Chaparro, P.J.; Esposito, F.; Sartori, L.; Dropa, M.; Matté, M.H.; Lira, D.P.A.; et al. First Report of the Globally Disseminated IncX4 Plasmid Carrying the $m c r-1$ Gene in a Colistin-Resistant Escherichia coli Sequence Type 101 Isolate from a Human Infection in Brazil. Antimicrob. Agents Chemother. 2016, 60, 6415-6417. [CrossRef] [PubMed]

88. Gerhold, G.; Schulze, M.H.; Gross, U.; Bohne, W. Multilocus sequence typing and CTX-M characterization of ESBL-producing E. coli: A prospective single-centre study in Lower Saxony, Germany. Epidemiol. Infect. 2016, 144, 3300-3304. [CrossRef] [PubMed]

89. Khan, E.R.; Aung, M.S.; Paul, S.K.; Ahmed, S.; Haque, N.; Ahamed, F.; Sarkar, S.R.; Roy, S.; Rahman, M.M.; Mahmud, M.C.; et al. Prevalence and Molecular Epidemiology of Clinical Isolates of Escherichia coli and Klebsiella pneumoniae Harboring Extended-Spectrum Beta-Lactamase and Carbapenemase Genes in Bangladesh. Microb. Drug Resist. 2018, 24, 1568-1579. [CrossRef] [PubMed]

90. Pfeifer, Y.; Witte, W.; Holfelder, M.; Busch, J.; Nordmann, P.; Poirel, L. NDM-1-producing Escherichia coli in Germany. Antimicrob. Agents Chemother. 2011, 55, 1318-1319. [CrossRef] [PubMed]

91. Williamson, D.A.; Freeman, J.T.; Roberts, S.A.; Heffernan, H.; Dyet, K.; Paterson, D.L.; Rogers, B.A.; Sidjabat, H.E.; Masters, J. Rectal colonization with New Delhi metallo-lactamase-1-producing Escherichia coli prior to transrectal ultrasound (TRUS)-guided prostate biopsy. J. Antimicrob. Chemother. 2013, 68, 2957-2959. [CrossRef]

92. Potron, A.; Poirel, L.; Rondinaud, E.; Nordmann, P. Intercontinental spread of OXA-48 beta-lactamase-producing Enterobacteriaceae over a 11-year period, 2001 to 2011. Eurosurveillance 2013, 18, 20549. [CrossRef]

93. Samuelsen, Ø.; Overballe-Petersen, S.; Bjørnholt, J.V.; Brisse, S.; Doumith, M.; Woodford, N.; Hopkins, K.L.; Aasnæs, B.; Haldorsen, B.; Sundsfjord, A.; et al. Molecular and epidemiological characterization of carbapenemase-producing Enterobacteriaceae in Norway, 2007 to 2014. PLoS ONE 2017, 12, e0187832. [CrossRef] 
94. Mantilla-Calderon, D.; Jumat, M.R.; Wang, T.; Ganesan, P.; Al-Jassim, N.; Hong, P.-Y. Isolation and Characterization of NDM-Positive Escherichia coli from Municipal Wastewater in Jeddah, Saudi Arabia. Antimicrob. Agents Chemother. 2016, 60, 5223-5231. [CrossRef]

95. Braga, J.F.V.; Chanteloup, N.K.; Trotereau, A.; Baucheron, S.; Guabiraba, R.; Ecco, R.; Schouler, C. Diversity of Escherichia coli strains involved in vertebral osteomyelitis and arthritis in broilers in Brazil. BMC Vet. Res. 2016, 12, 140. [CrossRef]

96. Koo, H.-J.; Kwak, H.-S.; Yoon, S.-H.; Woo, G.-J. Phylogenetic group distribution and prevalence of virulence genes in Escherichia coli isolates from food samples in South Korea. World J. Microbiol. Biotechnol. 2012, 28, 1813-1816. [CrossRef]

97. Müller, A.; Jansen, W.; Grabowski, N.T.; Monecke, S.; Ehricht, R.; Kehrenberg, C. ESBL- and AmpC-producing Escherichia coli from legally and illegally imported meat: Characterization of isolates brought into the EU from third countries. Int. J. Food Microbiol. 2018, 283, 52-58. [CrossRef] [PubMed]

98. Xie, M.; Lin, D.; Chen, K.; Chan, E.W.C.; Yao, W.; Chen, S. Molecular Characterization of Escherichia coli Strains Isolated from Retail Meat That Harbor blaCTX-M and fosA3 Genes. Antimicrob. Agents Chemother. 2016, 60, 2450-2455. [CrossRef] [PubMed]

99. Wu, C.; Wang, Y.; Shi, X.; Wang, S.; Ren, H.; Shen, Z.; Wang, Y.; Lin, J.; Wang, S. Rapid rise of the ESBL and mcr-1 genes in Escherichia coli of chicken origin in China, 2008-2014. Emerg. Microbes Infect. 2018, 7, 1-10. [CrossRef] [PubMed]

100. Boehmer, T.; Vogler, A.J.; Thomas, A.; Sauer, S.; Hergenroether, M.; Straubinger, R.K.; Birdsell, D.; Keim, P.; Sahl, J.W.; Williamson, C.H.D.; et al. Phenotypic characterization and whole genome analysis of extended-spectrum beta-lactamase-producing bacteria isolated from dogs in Germany. PLoS ONE 2018, 13, e0206252. [CrossRef] [PubMed]

101. Zhou, X.; García-Cobos, S.; Ruijs, G.J.H.M.; Kampinga, G.A.; Arends, J.P.; Borst, D.M.; Möller, L.V.; Holman, N.D.; Schuurs, T.A.; Bruijnesteijn van Coppenraet, L.E.; et al. Epidemiology of Extended-Spectrum $\beta$-Lactamase-Producing E. coli and Vancomycin-Resistant Enterococci in the Northern Dutch-German Cross-Border Region. Front. Microbiol. 2017, 8, 1914. [CrossRef]

102. Wang, Y.; Tian, G.-B.; Zhang, R.; Shen, Y.; Tyrrell, J.M.; Huang, X.; Zhou, H.; Lei, L.; Li, H.-Y.; Doi, Y.; et al. Prevalence, risk factors, outcomes, and molecular epidemiology of mcr-1-positive Enterobacteriaceae in patients and healthy adults from China: An epidemiological and clinical study. Lancet Infect. Dis. 2017, 17, 390-399. [CrossRef]

103. Shrestha, B.; Tada, T.; Miyoshi-Akiyama, T.; Shimada, K.; Ohara, H.; Kirikae, T.; Pokhrel, B.M. Identification of a novel NDM variant, NDM-13, from a multidrug-resistant Escherichia coli clinical isolate in Nepal. Antimicrob. Agents Chemother. 2015, 59, 5847-5850. [CrossRef]

104. Herrero-Fresno, A.; Zachariasen, C.; Hansen, M.H.; Nielsen, A.; Hendriksen, R.S.; Nielsen, S.S.; Olsen, J.E. Apramycin treatment affects selection and spread of a multidrug-resistant Escherichia coli strain able to colonize the human gut in the intestinal microbiota of pigs. Vet. Res. 2016, 47, 12. [CrossRef]

105. Trobos, M.; Lester, C.H.; Olsen, J.E.; Frimodt-Moller, N.; Hammerum, A.M. Natural transfer of sulphonamide and ampicillin resistance between Escherichia coli residing in the human intestine. J. Antimicrob. Chemother. 2009, 63, 80-86. [CrossRef]

106. Duriez, P.; Clermont, O.; Picard, B.; Denamur, E.; Bonacorsi, S.; Bingen, E.; Chaventré, A.; Elion, J. Commensal Escherichia coli isolates are phylogenetically distributed among geographically distinct human populations. Microbiology 2001, 147, 1671-1676. [CrossRef] [PubMed]

107. Hallström, T.; Resman, F.; Ristovski, M.; Riesbeck, K. Binding of complement regulators to invasive nontypeable Haemophilus influenzae isolates is not increased compared to nasopharyngeal isolates, but serum resistance is linked to disease severity. J. Clin. Microbiol. 2010, 48, 921-927. [CrossRef] [PubMed]

108. Hughes, C.; Phillips, R.; Roberts, A.P. Serum resistance among Escherichia coli strains causing urinary tract infection in relation to $\mathrm{O}$ type and the carriage of hemolysin, colicin, and antibiotic resistance determinants. Infect. Immun. 1982, 35, 270-275. [CrossRef] [PubMed]

109. Adler, N.R.L.; Stevens, M.P.; Dean, R.E.; Saint, R.J.; Pankhania, D.; Prior, J.L.; Atkins, T.P.; Kessler, B.; Nithichanon, A.; Lertmemongkolchai, G.; et al. Systematic Mutagenesis of Genes Encoding Predicted Autotransported Proteins of Burkholderia pseudomallei Identifies Factors Mediating Virulence in Mice, Net Intracellular Replication and a Novel Protein Conferring Serum Resistance. PLoS ONE 2015, 10, e0121271. [CrossRef] [PubMed] 
110. Desroches, M.; Clermont, O.; Lafeuillade, B.; Rodriguez, C.; Darty, M.; Royer, G.; Bouvet, O.; Ounnoughene, N.; Noizat-Pirenne, F.; Denamur, E.; et al. Genotypic and phenotypic characteristics of Escherichia coli involved in transfusion-transmitted bacterial infections: Implications for preventive strategies. Transfusion 2018, 58, 1940-1950. [CrossRef]

111. Peirano, G.; Mulvey, G.L.; Armstrong, G.D.; Pitout, J.D.D. Virulence potential and adherence properties of Escherichia coli that produce CTX-M and NDM $\beta$-lactamases. J. Med. Microbiol. 2013, 62, 525-530. [CrossRef] [PubMed]

112. Scott, V.C.S.; Haake, D.A.; Churchill, B.M.; Justice, S.S.; Kim, J.H. Intracellular Bacterial Communities: A Potential Etiology for Chronic Lower Urinary Tract Symptoms. Urology 2015, 86, 425-431. [CrossRef]

113. Rivardo, F.; Martinotti, M.G.; Turner, R.J.; Ceri, H. Synergistic effect of lipopeptide biosurfactant with antibiotics against Escherichia coli CFT073 biofilm. Int. J. Antimicrob. Agents 2011, 37, 324-331. [CrossRef]

114. Wu, H.; Moser, C.; Wang, H.Z.; Høiby, N.; Song, Z.J. Strategies for combating bacterial biofilm infections. Int. J. Oral Sci. 2015, 7, 1-7. [CrossRef]

115. Kjelstrup, C.K.; Barber, A.E.; Norton, J.P.; Mulvey, M.A.; L'Abée-Lund, T.M. Escherichia coli O78 isolated from septicemic lambs shows high pathogenicity in a zebrafish model. Vet. Res. 2017, 48. [CrossRef]

116. Hauser, E.; Mellmann, A.; Semmler, T.; Stoeber, H.; Wieler, L.H.; Karch, H.; Kuebler, N.; Fruth, A.; Harmsen, D.; Weniger, T.; et al. Phylogenetic and molecular analysis of food-borne shiga toxin-producing Escherichia coli. Appl. Environ. Microbiol. 2013, 79, 2731-2740. [CrossRef] [PubMed]

117. Mellmann, A.; Bielaszewska, M.; Köck, R.; Friedrich, A.W.; Fruth, A.; Middendorf, B.; Harmsen, D.; Schmidt, M.A.; Karch, H. Analysis of Collection of Hemolytic Uremic Syndrome-associated Enterohemorrhagic Escherichia coli. Emerg. Infect. Dis. 2008, 14, 1287-1290. [CrossRef] [PubMed]

118. Bai, X.; Mernelius, S.; Jernberg, C.; Einemo, I.M.; Monecke, S.; Ehricht, R.; Löfgren, S.; Matussek, A. Shiga toxin-producing Escherichia coli infection in Jönköping county, Sweden: Occurrence and molecular characteristics in correlation with clinical symptoms and duration of stx shedding. Front. Cell. Infect. Microbiol. 2018, 8, 125. [CrossRef] [PubMed]

119. Ferdous, M.; Friedrich, A.W.; Grundmann, H.; de Boer, R.F.; Croughs, P.D.; Islam, M.A.; Kluytmans-van den Bergh, M.F.Q.; Kooistra-Smid, A.M.D.; Rossen, J.W.A. Molecular characterization and phylogeny of Shiga toxin-producing Escherichia coli isolates obtained from two Dutch regions using whole genome sequencing. Clin. Microbiol. Infect. 2016, 22, 642. [CrossRef]

120. Jønsson, R.; Struve, C.; Jenssen, H.; Krogfelt, K.A. The wax moth Galleria mellonella as a novel model system to study Enteroaggregative Escherichia coli pathogenesis. Virulence 2017, 8, 1894-1899. [CrossRef] [PubMed]

121. Guerrieri, C.G.; Pereira, M.F.; Galdino, A.C.M.; dos Santos, A.L.S.; Elias, W.P.; Schuenck, R.P.; Spano, L.C. Typical and Atypical Enteroaggregative Escherichia coli Are Both Virulent in the Galleria mellonella Model. Front. Microbiol. 2019, 10. [CrossRef]

122. Heitmueller, M.; Billion, A.; Dobrindt, U.; Vilcinskas, A.; Mukherjee, K. Epigenetic mechanisms regulate innate immunity against uropathogenic and commensal-like Escherichia coli in the surrogate insect model Galleria mellonella. Infect. Immun. 2017, 85. [CrossRef]

123. Ciesielczuk, H.; Betts, J.; Phee, L.; Doumith, M.; Hope, R.; Woodford, N.; Wareham, D.W. Comparative virulence of urinary and bloodstream isolates of extra-intestinal pathogenic Escherichia coli in a Galleria mellonella model. Virulence 2015, 6, 145-151. [CrossRef]

(C) 2020 by the authors. Licensee MDPI, Basel, Switzerland. This article is an open access article distributed under the terms and conditions of the Creative Commons Attribution (CC BY) license (http://creativecommons.org/licenses/by/4.0/). 